\title{
Resmi Evrak Neden Saklanır/İmha Edilir? Osmanlı İmparatorluğu'nda Evrak İmha Uygulamalarına Yönelik Bir Değerlendirme*
}

\section{Why are Official Documents Kept/Destroyed? An Evaluation of Document Destruction Practices in the Ottoman Empire}

\author{
İshak Keskin ${ }^{1}$
}

*Bu makale; 3-4 Nisan 2014 tarihlerinde Kırgızistan Bişkek'te düzenlenen I. Uluslararası Türk Devlet Yönetimi Kongresi'nde "Osmanlı Bürokrasisinde Evrak İmha Uygulamalarına Dair Gözlemler" başlığı ile sunulan ve Türk Devlet Yönetimi Geleneği / ТҮРК ЭЛДЕРИНДЕГИ МАМЛЕКЕТ БАШКАРУУ САЛТЫ -Bildiriler Kitab1- Cengiz Buyar, Mehmet Kıldıroğlu ve Muratbek Kocabekov (Eds.) içinde (2016, s. 315-321) yayımlanan bildiri metninin genişletilmiş ve gözden geçirilmiş halidir.

'Prof. Dr., İstanbul Üniversitesi, Edebiyat Fakültesi, Bilgi ve Belge Yönetimi Bölümü, İstanbul, Türkiye

ORCID: İ.K. 0000-0003-1611-1330

Sorumlu yazar/Corresponding author: İshak Keskin,

İstanbul Üniversitesi, Edebiyat Fakültesi, Bilgi ve Belge Yönetimi Bölümü, İstanbul, Türkiye E-posta: ishak.keskin@istanbul.edu.tr

Başvuru/Submitted: 15.09 .2021

Kabul/Accepted: 22.10 .2021

Online Yayın/Published Online: 09.12.2021

Atıf/Citation: Keskin, İ. (2021). Resmi evrak neden saklanı/imha edilir? Osmanlı İmparatorluğu'nda evrak imha uygulamalarına yönelik bir değerlendirme. Bilgi ve Belge Araștırmaları Dergisi, 16, 1-28.

http://doi.org/10.26650/bba.2021.16.996193
ÖZ

Osmanlı devlet bürokrasisinde evrak imha uygulamalarına zaman zaman tesadüf edilmektedir. II. Mahmud'un askeri reformları esnasında yeniçerilere ait evrak ile yine Çırağan Sarayı'nda muhafaza edilen II. Abdülhamid devri istihbarat jurnalleri dönemin yetkilileri tarafından imha edilmiştir. Bu iki uygulamanın dışında Osmanlı döneminde evrak imhasına ait daha başka münferit örnekler de söz konusudur. Bütün bu uygulamaların Osmanlı bürokratları tarafından hangi gerekçelerle gerçekleștirildiği ve bu gerekçelerin bir teorik temele dayandırılıpdayandırıl(a)mayacağı araştırılmaya muhtaçtır. Bu çalışma; -uygulama örneklerinden hareketleOsmanlı Devleti dönemi evrak imha uygulamaları hakkında temel yaklaşımları belirleme konusunda sonuçlar elde etmeyi amaçlamaktadır. Yine -hukukî ve idarî zemini hazırlanmıș olsun veya olmasın- bu dönemde hayata geçirilen evrak imha uygulamalarının genel bir karakter sergileyip-sergilemediği yahut bunlardan hareketle Osmanlı döneminde evrak imha uygulamalarını teorik bir yaklaşım sergileyip-sergilemediği -veya bilimsel bir karaktere sahip olup-olmadığı- araştırılmaya çalışılmıştır. Araştırmada nitel araştırma yönteminden ve durum çalışmasından yararlanılmış olup, verilerin analizi için doküman analizi tekniğine başvurulmuştur.

Anahtar kelimeler: Osmanlı İmparatorluğu, arşivcilik, bürokrasi, değerlendirme, saklama planı, evrak/belge imhası

\section{ABSTRACT}

In the Ottoman State bureaucracy, various document destruction practices are seen. During the military reform period of Mahmud II, documents related to the Janissaries and the intelligence journals of Abdülhamid II that were preserved in Çırağan Palace were destroyed by the authorities of the period. Apart from these two practices, there were some other individual cases of document destruction too in the Ottoman period. The reasons why Ottoman bureaucrats practiced these acts of document destruction and whether the reasons were related to a theoretical basis or not are open to further research. The aim of this article is to consider some examples and draw significant conclusions regarding the main approaches on the issue of document destruction during the Ottoman period. Another aim is to examine whether those practices -regardless of whether they were carried out on a legal and administrative basis- had a common character, whether those document destruction practices presented a theoretical approach, or whether they had a scientific quality or not. The study used the qualitative research method and case studies, and it used document analysis technique for data analysis.

Keywords: Ottoman Empire, archival science, bureaucracy, evaluation/appraisal, preservation plan/disposal list/retention schedule, document destruction 


\section{EXTENDED ABSTRACT}

Not all the documents produced by Ottoman institutions have survived up to this day. Among the important reasons for this are indifference, carelessness, negligence, inadequate warehouse conditions, ignorance, transportation (moving), floods, intention, fire, war, and internal security problems. In addition to these reasons, there are also document destruction examples that were practiced by first having obtained legal permissions. Yet, while some of the destruction practices carried out by the Ottoman bureaucracy have acceptable justifications in terms of today's document destruction practices, some others do not. There is even a particular case of destruction which was carried out without any justification or permission.

Some of the Ottoman document destruction practices have aspects that can be considered positive in terms of bureaucratic and administrative needs while some others have some aspects that can be considered negative. Initiatives and practices in which those kinds of concerns played a dominant role include the destruction of some books belonging to the Janissaries in the period of Mahmud II (r. 1808-1839), the destruction of some documents and books from 1848-1850, the destruction decision in 1903, a similar decision in 1914, and the draft regulation of the destruction of documents in 1917. The destruction of the intelligence journals by the revolutionary administration at the end of the period of Abdülhamid II (r. 1876-1909) has a negative aspect in terms of document destruction. It is noteworthy that a significant part of the practices under the first group, which is considered positive in terms of document destruction, are based on acceptable administrative, legal and financial reasons - even partially scientific in terms of today's criteria. However, the destruction of the intelligence journals of the period of Abdülhamid II is the product of a completely subjective attitude and has no meaning in terms of modern archival theory and practice.

Looking at both the practices carried out and the prepared draft regulation, it is understood that the Ottoman destruction practices had a certain and acceptable basis. This also points to a considerably acceptable practice in terms of today's archival profession and theory. However, there were also cases of document destruction that can easily be evaluated as having been outside the acceptable practices in terms of the archival profession. This shows that there were two completely different document destruction practices in the Ottoman bureaucracy. These two completely different practices can be characterized as follows:

1) Intentional destruction: The act of deliberately destroying documents without leaving any trace means that the possibility of their use in the future was ignored. The purpose of this application is only to destroy the existing documents. There is no other concern except this. 
2) Destruction with concern for use: Document destruction practices in the Ottoman period generally had a certain concern for the future from administrative, financial and legal aspects. On the other hand, it was accepted that the documents that do not have administrative, financial and legal importance could be destroyed. This shows that the document destruction practices included in the second group were carried out with institutional and public concerns.

Each of those two methods for the destruction of documents points to two different tendencies in terms of the archival destruction theory. Those tendencies can be stated as follows:

1) The tendency in which only the idea of the destruction of documents is dominant: This tendency has no importance in terms of the theory of destruction. Destroying the document so that it will not be used later is the main concern. It is not possible to think that these practices make sense in the context of the Ottoman document destruction theory and that they give a character to the Ottoman destruction practices.

2) The tendency that takes into account state and public needs with regard to its aims and concerns: This tendency is very close to today's understanding of archival practices. Evaluations made under this tendency consider that the piles of documents in warehouses make it difficult for administrative archival research, create difficulties in the planning of institutional activities, and can function as an actor in the protection of the rights of institutions and individuals. Thus, it is questioned whether the concerned document would be used in subsequent institutional processes.

In today's document destruction practices, whether the document can be used in scientific research is an important issue. None of the Ottoman document-destruction practices reflects a clear statement related to keeping the documents permanently because of their research value. However, it is possible to say that the "research value" of the document was implicitly taken into account in the destruction practices of the Ottoman period. It is seen that there was a tendency to preserve documents that could shed light on history. However, it is unclear whether this tendency aimed to provide resources for scientific studies. In the only case that will serve as an example to the subject, it was requested in 1917 that the documents of historical importance be transferred to the War Archive in the War History Department of the Ministry of War. Although the need for research and researchers was not mentioned here, it is clear that the Ministry of War was establishing an archive to investigate the war tactics of the ancient times. The request for the collection of archival documents related to the history of war for the War Archive concerned, is, in a sense, like an implicit answer to the fact that the scientific research value of the document was known. However, this can, on the other hand, only be the result of a tendency to know the war tactics of the previous periods in terms of training specialist personnel and meeting institutional and even national and military needs. 
Considering that the Western countries of that period established institutions such as "war archives" it can be claimed that the Ottoman military authorities were aware of a similar need and developed an institutional perspective to meet this need. However, it is true that the view that archival documents could be used in scientific research, which was an idea that the Ottoman understanding of science took into consideration, was not common and it was not, therefore, openly stated. 


\section{GíRiş}

Osmanlı kurumlarının varlığını devam ettirdiği yaklaşık altı asır boyunca ürettiği belgelerin tamamının günümüze kadar ulaşmadığı konunun ilgilileri tarafından bilinmektedir. Bu belgelerin bir kısmının günümüze kadar ulaş(a)mamasının belli birtakım nedenleri bulunmaktadır. İlgisizlik, ${ }^{1}$ dikkatsizlik, ${ }^{2}$ ihmal (Abdurrahman Şeref Bey, 1326, s. 14; Uzunçarşıll, 1988, ss. 77, 254; Osmanlı arşiv bülteni, 1990, s. 10; Binark, 1980/a, ss. 31-32; Aky1ldız, 1995, s. 71; Belgelerle arşivcilik tarihimiz, 2000, s. 8), depo şartlarında yetersizlik, ${ }^{3}$ bilinçsizlik, ${ }^{4}$ nakil

11846 tarihli bir mazbataya göre, “[...] birbirine karuşub yırtılarak, Defterhâne'de olanlar dahi perîşân durarak lede'l-1̂câb evrâk-1 atîka aranıldıkda, bulunması imkân derecelerinden çıkmış olduğundan ve belki çoğu telef ve zâyi olmuş olduğundan [...]" (Başkanlık Osmanlı Arşivi [BOA], İ. MSM., 25/658; Aktaş, 1985, s. 68) söz edilmekte; 16 Haziran [1]326 / 28 Haziran 1910 tarihli bir başka belgede ise "Matbâ'alardan satılan lüzûmsuz evrâk miyânında tezkire-i Osmânîye gibi evrâk-1 resmîye bulundurulduğundan dikkat-i mütemâdîye icrâsına dâ'ir [...]" ifadeleri ilgisizlik nedeniyle evrakın yok olduğunu açık bir şekilde göstermektedir (BOA. DH. SN. THR. 8/62; naklen Belgelerle arşivcilik tarihimiz, 2000, s. 254). Bir başka belgede "[...] Muhâsebenin Zabtiyye Nezâreti zamânına â'id kuyûdât ve mu'âmelâtına dâ'ir [...] evrâk ve defâtîrin [...] hemân kâmilen Bâyezid'deki polis merkezinin alt katındaki bir odada perîşân bir hâlde terk ediliverdiği görülmüş olmağın [...]" (BOA. DH. EUM. MH., 123/17; naklen Belgelerle arşivcilik tarihimiz, 2000, s. 446) şeklindeki ifade de yine bu durumu teyit etmektedir.

2 Ahmed Lütfî Efendi, lazım olduğunda alınan evrakın işi bittiğinde gelişigüzel mahzenlere atılmasından şikâyet ederek, Belgrat ile ilgili bir araştırma yapıldığında, ilgili torbanın içinde Bağdat'a ait evrakın bulunması gibi olumsuzluklarla karşılaşıldığına işaret etmektedir (Ahmed Lütfî Efendi, 1328, ss. 119-121; aynı yazar, 1999, ss. 1230-1231; Aky1ldız, 2004, s. 145). Nitekim mahzenlerde -sözde- korunan evrakın düzensizliği, iyi korunamaması ve ciddi bir koruma önleminin de alın(a)mamış olması 1845 sürecinde yapılan arşiv çalışmasının temel nedeni olarak karşımıza çıkmaktadır (Başbakanlık Osmanlı Arşivi rehberi, 2000, s. XLIV; Keskin, 2007, s. 294). Yine Dâhiliyye Nezâreti'nden Umûm Vilâyât ve Elviye-i Gayr-i Mülhakaya 24 Kânûn-1 Sânî [1]326 tarihinde yazılan bir telgrafta geçen "[...] elde ve taht-1 mu'âmelede bulunan evrâk muhterik olduğundan [...]" (BOA. DH. MTV. 47/4; naklen Belgelerle arşivcilik tarihimiz, 2000, s. 255) şeklindeki ifade, dikkatsizlik sonucu birtakım evrakın yok oluğunu açık bir şekilde teyit etmektedir. Aynı konuya büro ve çevresinin evrak yığınlarıyla dolu olduğundan söz eden Carter V. Findley (1996, s. 234) de değinmiştir.

3 Örneğin "[...] Bâbıâlî ve devâ'ir-i sâ’irenin evrâk-1 mühimmeleri hıfz olunan mahzenin Dîvân-1 Hümâyûn Dâ'iresi kısmı fevka'l-âde harâbiyeti cihetiyle [...] selâtîn-i mâzîye [...] zamânlarında verilen evâmir-i şerîfelerin küllîsi hâk ile yeksân olmuş ve bu hâl devâm etdikce devletce ve efrâdca lüzûm göründükce aranılan evrâk elde edilemeyeceği bedîhî bulunmuş olmağın [...]" ifadesi bunu teyit etmektedir (BOA. Y. EE. 30/124/51/78; naklen Belgelerle arşivcilik tarihimiz, 2000, s. 206). Ayrıca 15 Mayıs 1845 tarihli bir belgede ise " [...] Enderûn-1 Hümâyûn'da olup evrâk ve defâtir-i atîka-i mu’tebere hıfz olunan Hazîne-i Behiyye'de mevcûd evrâk külliyen telef olmak râddesine gelmiş olduğundan [...]" (BOA. BEO. Ayniyat Def. 769/51; BOA. İ. Dâhiliye, 5152; Belgelerle arşivcilik tarihimiz, 2000, ss. 273-275), “[...] Meyve Gümrüğü anbârı derûnunda olup bir takım evrâk konulmakda olan mahallin sakfı çökmesi hasebiyle [...]" (BOA. İ. Şûrâ-yı Devlet, 3560; Belgelerle Arşivcilik Tarihimiz, 2000, ss. 403-405), “[...] Dâ’ire-i Sthhiyye'nin evrâk-1 mühimmesiyle defâtîrinin ahşab dâ'ire dâhilinde bulundurulması mahzûrdan sâlim olamayacağı cihetle [...]" (Belgelerle arşivcilik tarihimiz, 2000, ss. 433-434; BOA. İ. Sıhhiye, 1317 R./1); “[...] rutûbetden derûnundaki defâtir ve evrâk nemlenerek okunmayacak ve ele alınmayacak derecede çürümekde olduğu [...]" (BOA. İ. Şûrâ-yı Devlet, 2450; Belgelerle Arşivcilik Tarihimiz, 2000, ss. 462-463) şeklindeki ifadeler bu duruma yeterli açılama getirmektedir.

4 Kimi zamanlar üst düzey bürokratların (nazırların) kendileriyle ilişkiliymiş gibi bazı tazkireleri alıkoydukları, ölümleri sonrasında anlaşılmıştır. Belgede " [...] şeref-sudûr buyurulan irâdât-1 seniyye-i mülûkâneyi mübelliğ tastîr ve devâ'ir-i müte 'allikasına irsâl kılınan tezâkir maslahat-ı devlete müte'allik teblîgâtı mutazammın ve binâ'en-aleyh makâma â'id olarak Hazîne-i Evrâk'da hıfz olunmak lâzım geldiği hâlde nüzzâr vesâ' ire taraflarından bu tezkireler zâtlarına müte'allik imiş gibi nezdlerinde alıkonulduğu vefât eden bazı zevâtın evrâkı miyânında bi't-tefrîk â'ileleri tarafindan arz u takdîm kılınan tezkirelerden anlaşıllmış [...]"tır denilerek bu duruma işaret edilmiştir (BOA. Y.A.RES., 108/82; Belgelerle arşivcilik tarihimiz, 2000, ss. 250-255). 
(taşınma), ${ }^{5}$ su baskınları (Çetin, 1984, s. 56), kasıt, ${ }^{6}$ yangın, ${ }^{7}$ savaş ${ }^{8}$ ve iç asayiş sorunları ${ }^{9}$ gibi doğrudan etkenler bunun belli başlı nedenleri arasında gösterilebilir (Çetin, 1984, ss. 53-65).

Yukarıda belirtilmiş olan açık sebeplerin dışında, Osmanlı devlet kurumlarına ait evrakın günümüze ulaş(a)mamasına neden olan başka etkenler de bulunmaktadır. Bu sebeplerden biri, -haklı nedenlere dayanan veya dayanmayan bazı amaçlar doğrultusunda- yasal izinler alınmak suretiyle evrakın imha yoluyla yok edilmesidir. Bu uygulamaların gerekçeleri -ve teorik bakış açıları- genellikle bugün bile makul kabul edilebilecek durumdadır. Diğer bir kısım imha uygulamasının ise buna karşın, günümüz için kabul edilebilir bir gerekçeye ve teorik bir temele sahip olmadığı ifade edilebilir. Başka bir ifade ile her imha uygulamasının -bürokratik ve arşivcilik uygulamaları bakımlarından olumsuz örnek teşkil etmesinin dışında- bürokratik ihtiyaçlar ve arşiv teorisi bakımından bir anlam ihtiva etmesi söz konusu değildir. Evrakın yok oluşuna sebep olan bu gelişmelerin, evrak imhasıyla ilgili olarak mesleki açıdan teorik bir temel sunması kuşkusuz beklenemez. Zira bu uygulamalar, evrakın yok oluşuyla ilgili herhangi bir kaygı ve içinde -açık veya örtük- herhangi bir neden barındırmayan hadiseler olarak Türk arşivcilik tarihinin kötü hatırlanan gelişmeleri şeklinde kayda geçmiştir.

5 Örneğin "[...] Erzincan merkez kazâsıyla mülhakâtdan Refahiye ve Pülümür kazâları nüfûs kuyûdâtının esnâ-yı tahlîyede vesâ'itsizlik yüzünden çıkarılamayarak bunlardan Erzincan Pülümür kuyûdâtının kâmilen ve Refahiye kuyûdâtının kısmen ziyâ’a uğradığı [...]" ifade edilmektedir (BOA. DH. SN. THR.. 81/70; Belgelerle Arşivcilik Tarihimiz, 2000, s. 518).

611 Mayıs 1845 tarihli bir belgede geçen “[...] hazîne-i mezkûrede mülgâ ocaklara mütedâ'ir biraz evrâk ve defâtir-i atîka ile cizye kâğıdları bulunarak bunların [...] hark ile ortadan kaldırılması münâsib göründüğünden [...]" ifadesi, bazı zamanlarda kasıtlı olarak evrak imhası cihetine gidildiğini göstermektedir (BOA. BEO. Ayniyat Def., 769/51; BOA. İ. Dâhiliye, 5152; Belgelerle Arşivcilik Tarihimiz, 2000, ss. 273-275).

7 Örneğin "[...] Avrethisârı kazâsı hükûmet konağında tapuya müte'allik muhterik olan kuyûdun [...]" (BOA. İ. Şûrâ-y1 Devlet 4436; Belgelerle arşivcilik tarihimiz, 2000, ss. 467-468) ve "[...] Karahisâr-1 Şarkî nüfûs kuyûdâtı muhterik olmasına mebni [...]" (BOA. DH. SN. THR., 68/83; Belgelerle arşivcilik tarihimiz, 2000, ss. 511-513) ifadeleri bu durumu teyit etmektedir. Ayrıca ilk dönem Osmanlı evrakının Bursa'da Timur istilası sırasında çıkan karmaşa dolayısıyla ve yangın münasebetiyle yok olduğu iddiası bulunmaktadır (Akyıldız, 1995, s. 69; "Osmanlı Arşivi Tarihçesi", 1990, s. 9). Aynı dönem evrakının başkentin Edirne'ye taşınmasından sonra burada çıkan bir yangında telef olduğu bilgisi de aynı yönde bir duruma işaret etmektedir ("Osmanlı Arşivi Tarihçesi”, 1990, s. 9). Yine Babıâli'deki yangınlar neticesinde mahzenlere konulmayıp bürolarda tutulan pek çok evrakın yandığı bilinmektedir (Çınar, 1999, s. 89).

8 “[...] Yunan muhârebesi esnâsında mahv u zâyi" olan Loros kazâsı hükûmet evrâkıyla nüfûs defâtîrinin [...]” (BOA. İ. Dahiliye, 1316 R./17; Belgelerle arşivcilik tarihimiz, 2000, ss. 484-485), "“...] istîlâ esnâsında Revânduz'da terk edilüp telef edilen evrâk ve kuyûdâtın [...]" (BOA. DH. SN. THR., 71/11; Belgelerle arşivcilik tarihimiz, 2000, ss. 513-514) ve "[...] Giresun kazâsı hükûmet dâ'iresinin bombardımana uğramasından dolayı nüfûs ve tapu devâ' îrine â’id kuyûdun [...]" (BOA. DH. MB. HPS., 46/42; Belgelerle Arşivcilik Tarihimiz, 2000, ss. 515-516) yandığı ifadeleri bu duruma örnek teşkil etmektedir. Ayrıca savaşların Osmanlı evrakı ve arşivleri üzerindeki etkisi hakkında Çetin (1987, ss. 6-8) ve Emecen (1991, ss. 241-259) tarafindan çalışmalara bakıllabilir.

928 Muharrem 327 tarihli bir belgede "[...] Alaşehir'de redif zâbıtânının birinin teşvîkâtıyla bir cemm-i gafîr adliye dâiresine hücûm ve hey'et-i hâkimeyi tard etdikten sonra evrâk ve defâtiri ihrak eyledikleri [...] bu hâlin yalnız kazâ-i mezbûra münhasır olmayub bidâyet-i inkılâbda ve bâ-husus efrâd-1 redîfenin Rumeli'den hîn-i avdetinde her tarafda yapılan nümâyişler esnâsında ekser kazâların mehâkim ve hattâ eytâm dâireleri ve devâ'îr-i sâire evrâkının da imha ve ihrak edilmiş olduğu [...]" (BOA. DH.MUI., 55-1/7, 1328.M.14) şeklinde geçen ifadelerden de anlaşılacağı üzere, asayiş sorunlarının mevcut Osmanlı evrakının yok olmasına sebep olduğu anlaşılmaktadır. 
İmha uygulamalarının arşiv teorisi bakımından bir anlam ifade edebilmesi için, gerekçelerinin imha teorisi bakımından dikkate alınabilir olması gereklidir. Son dönem Osmanlı bürokratik uygulamalarında kendisine yer bulmuş olan imha uygulamalarının -önemli?- bir kısmının bürokratik/idarî ihtiyaçlar bakımından olumlu yorumlanabilir yönü bulunmaktadır. II. Mahmud döneminde (sal. 1808-1839) Yeniçeri ocağına ait bazı defterlerin imhası, 1848-1850 yıllarına ait bazı evrakın ve defterlerin imhası, 1903 yılına ait imha kararı ve 1914 yılına ait benzeri bir karar ile 1917 yılına ait evrak imhasıyla ilgili nizamname bu türden kaygıların başat rol oynadığı uygulamalardır. Bu uygulamalar ayrıca araştırmanın konusuna örnek teşkil edebilir niteliklere de sahiptir. Bu uygulamaların bir kısmının yasal ve idarî altyapısının yanı sıra evrak imhasına ilişkin teorik bakış açısının -zamanın idarî ve bilimsel şartları göz önünde bulundurulmak kaydıyla- temellendirilmesi veya -günümüzde bile- kabul edilebilir idarî, hukukî ve malî -hatta kısmen bilimsel- nedenlere dayandırılmış olması ayrıca dikkat çekicidir.

Çalışma; -bilinen bazı örneklerden hareketle- Osmanlı Devleti dönemi evrak imha uygulamaları hakkında temel yaklaşımları belirleme konusunda sonuçlar elde etmeyi amaçlamaktadır. Yine -yasal ve idarî zemini hazırlanmış olsun veya olmasın- bu dönemde hayata geçirilen evrak imha uygulamalarının genel bir karakter sergileyip-sergilemediği yahut bunlardan hareketle Osmanlı döneminde evrak imha uygulamalarının teorik bir yanının (veya bilimsel bir karaktere sahip) olup-olmadığı araştırılmaya çalışılmıştır. Çalışmanın sorusu; "Osmanlı Devleti döneminde hayata geçirilen evrak imha uygulamalarının teorik bir temeli var mıdır?" şeklinde belirlenmiştir. Sorunu cevabı ise "Osmanlı Dönemi evrak imha uygulamalarının belli bir karakterinin olduğu ancak günümüz imha uygulamaları ile kısmen örtüştüğü, kısmen de örtüşmediği” şeklindedir. Nitel araştırma yönteminin uygulandığı bu çalışmanın deseni durum çalışması olarak kurgulanmıştır. Çalışmanın verileri literatür taraması ve arşiv araştırması ile elde edilmiş olup, verilerin değerlendirmesinde doküman analizi tekniğinden yararlanılmıştır.

\section{Arşivcilikte Modern İmha Uygulamalarının Doğuşu ve İmhanın Temel Karakteri}

Arşivcilikte imha konusuna ilişkin bilimsel bakış açılarının gelişmesi, beş bin yılı aşan arşivcilik tarihi bakımından oldukça geç bir tarihte gerçekleşmiştir. Yakın zamanlara kadar kurumsal evrak üretiminin baş edilebilir düzeyde kalması, belgelerin üretim aşamasından itibaren arşive ya da arşivcinin sorumluluğuna oldukça geç terk edilmiş olması, bilimsel paradigma değişiminin geç bir zamanda gerçekleşmiş olması ve araştırmaya dayalı bilimsel ihtiyacın belli bir zamandan sonra söz konusu olması bu durumun en temel nedenleri arasında sayılabilir. Bu nedenlere bağlı olarak ayıklamaya ve imhaya yönelik teorik yaklaşımların ve yöntem geliştirme çabalarının geciktiği görülmektedir. Bu konuya ilişkin ilk akademik yayınlara ve teorik yaklaşımların sergilendiği bakış açılarına 19. yüzyıldan itibaren tesadüf edilmektedir (Duchein, 2008, s. 44). Ancak bu konuda esas gelişmelerin görülebilmesi için neredeyse bir yüzyıl daha beklemek, yani yaklaşık olarak 20. yüzyılın ortalarını beklemek gerekmiştir. 
20. yüzyılın ilk yarısının sonlarına doğru özellikle teknik temelli gelişmelerin etkisiyle gerçekleşen yoğun belge üretimi, kurumlarda aynı zamanda çok miktarda belge üretilmesine, dolayısıyla kurumlarda çok sayıda belge birikmesine neden olmuştur. Kurumlarda meydana gelen bu evrak yı̆̆ılması, -meslekî bir değerlendirme işlemi sonucunda- üretilen her belgenin korunması gerekip-gerekmediği (veya nelerin imha edileceği veya nelerin korunacağı -Lamb, 1985, s. 251-) sorusunu gündeme taşımış; üretilen belgelerin "hangi neden(ler)le imha edilebileceği”" ya da üretilen belgelerin "hangi gerekçe(ler)le muhafaza edilebileceği” şeklindeki soru, imha uygulamasının hayata geçirilmesi bakımından önem kazanmıştır. Aynı zamanda seçme kriterlerini de ihtiva eden değerlendirme işleminin, hazırlanan saklama planlarıyla çözüme kavuşturulması düşüncesi böylelikle ortaya çıkmıştır. Bu teorik temele dayalı bilimsel tartışmaların başlangıcı ise neredeyse Sir Charles Hillary Jenkinson (1882-1961) (1922 ve 1937) ve Theodore Roosevelt Schellenberg (1903-1970) (Chicago, 1956, 1975, 1998; New York, 1965; Ankara, 1993) tarafından çoğunlukla yayınlar yoluyla ve oldukça akademik bir üslupla yürütülmüş olan karşılıklı ve hararetli bilimsel tartışmalara dayanmaktadır.

Modern arşivcilik literatüründe, evrakın imha veya muhafazasına dair uygulamaları belirten belgelere (Arşivcilik terimleri sözlüğü, 1995, s. 94), yönetmeliklere (Kandur, 1998, s. 45), tablolara (Aydın, 1999, s. 47) veya listelere (Dearstyne, 2001, s. 100) "saklama planı" denmektedir. Saklama planı, International Council on Archives / Uluslararası Arşiv Konseyi (ICA) tarafından hazırlanan ve pek çok dile çevrilen (ve Bekir Kemal Ataman tarafindan genişletilerek Türkçeye çevrilen) Arşivcilik Terimleri Sözlüğü’nde (1995, s. 94) “bir kurumun evrakları içinde arşivsel değere sahip olmaları sebebiyle saklanması gerekenleri niteleyen ve saklanmayacak olanların belirli saklama sürelerinin geçmesi veya belirli olay yahut da eylemlerin gerçekleşmesinden sonra imhasına, sürekli bir esas çerçevesinde izin veren belge" şeklinde açıklanmaktadır.

Belgelerin ispat ve bilgi bakımlarından değerleri, onların saklanmaları konusundaki kararların belirlenmesi için hayati bir öneme sahiptir. Saklama planlarının zamanında hazırlanmış olması halinde bu kararların kolaylıkla alınması mümkün olabilir. Saklama planlarıyla birlikte dosya/ defter serileri için idarî, malî, yasal ve araştırma nedenlerine yönelik uygun bir saklama süresi, yani sürekli saklanıp saklanmayacağı veya saklanmayacaksa üretiminden ne kadar zaman sonra imha edilmesi gerektiği belirlenmiş olur.

Arşiv teorisyenleri, -belge ayıklama-imha işleminin meşru olduğunu ikna edici bir şekilde ortaya koyarken- ayıklama-imha işlemini genel olarak iki temel gerekçeye dayandırırlar. Halen geçerli olan bu gerekçeler şu şekilde sıralanabilir (Duchein, 2008, s. 44; Dearstyne, 2001, s. 99):

1. Kamu ve özel kurumlar tarafindan üretilen belge kütlelerinin oldukları hacimde saklanmasının maddi olarak imkânsızlığıı. 
2. Belgelerin saklanmaları mümkün olsa bile- depolarda yoğun şekilde biriken evrakın kurum çalışanları ve araştırmacılar tarafından hızlı bir şekilde kullanımlarının güçleşeceği ihtimali.

Buradan hareketle yapılabilecek son bir değerlendirme ise şu şekilde sıralanabilir:

1. Arşiv varlıkları depo ve diğer maliyetler nedeniyle artık efektif ve etkili bir şekilde yönetilebilir olmaktan çıkmıştır. Bu sebeple, kurumsal arşiv varlıklarının yönetilebilir ve korunabilir bir ölçeğe indirgenmesi gerekmektedir.

2. Kurum çalışanlarının idarî süreçlerde kullanacakları idarî belgelere ve arşiv belgelerine erişimleri artık imkânsız gibidir. Bu sebeple, kurumsal arşiv varlıkları üzerinde ayıklama ve imha uygulamasının gerçekleştirilmesi gerekmektedir.

3. Araştırmacıların ele geçirmeyi arzuladıkları muhtemel arşiv kaynaklarına mümkün olan en hızlı bir şekilde erişebilmeleri artık imkân dâhilinde değildir. Bu sebeple, kurumsal arşiv varlıkları üzerinde ayıklama ve imha uygulaması yapılmalıdır.

\section{Osmanlı Evrak İmha Uygulamalarına Dair Örnekler}

Yaklaşık altı asrı aşan bir zaman boyunca -bilinen uygulama sayıları fazla olmasa da- Osmanlı Devleti'nde bazı evrak imha uygulamalarına tesadüf etmek mümkündür. Bununla birlikte, -konu hakkında bilinenlerin ortaya koyduğu gibi- 20. yüzyılın neredeyse hemen başlarından önce, imha işleminin hangi nedenlerle ve aşamalardan geçtikten sonra yapılabileceği konusunu açıklayan bir yasal düzenleme bulunmamaktadır. Zaten bu konuda hayata geçirilen ilk örnekler de bunu güçlü şekilde teyit eder niteliktedir.

Osmanlı bürokrasisinde evrak imha uygulamalarının ilk örnekleri imha işleminin, imhaya dair haklı gerekçelerin anlatıldığı genellikle kısa ve basit bir değerlendirme sonrasında gerçekleştirildiklerini göstermektedir. Bunu imha uygulamasına temel olan yazışmalardan hareketle söylemek mümkündür. -Başka örnekler olmakla birlikte- bunların en bilinenlerinden biri -çeşitli tarihi araştırmalara da konu olan- yeniçeri ocağının kaldırılışı sırasında; diğeri de, II. Abdülhamid (sal. 1876-1909) döneminde üretilmiş jurnallerin (istihbarat kayıtlarının), onun tahttan indirilişinden sonra (1909) imha edilmeleriyle yaşanmıştır.

II. Mahmud'un askeri reformları esnasında evrak imha uygulamaları konusunda -belki de- en anlamlı örneklerden biri yaşanmıştır. Bu örneğe göre yeniçerilere ait bir kısım evrakın imhası gerçekleştirilmiştir. Bu hadise, dönemin ve söz konusu kurumun özelliğinden dolayı bir yönüyle her ne kadar siyasî bir husus olarak karşımıza çıksa da, bir başka yönüyle de bilinen ilk evrak imha uygulamasıdır (Aydın, 1999, ss. 47-48; Aktaş, 1985, ss. 67-72; Akyıldız, 1995, ss. 76-77). Evrak imhasına ait tarihin kaydettiği diğer bir örnek de, Çırağan Sarayı'nda muhafaza edilen ve II. Abdülhamid devrinde oluşturulan jurnallerin II. Meşrutiyet hükümeti 
ve yetkilileri tarafından imhasıdır (Demiroğlu, 1955, ss. 6-9). Bu iki hadisenin dışında evrak imhasına ait daha başka münferit örneklerin bulunduğunu belirtmek mümkündür. Ancak II. Abdülhamid devrinde oluşturulan jurnallerin imhası meselesi bunlar arasında zamanın arşivcilik anlayışına bile uygun olmayan ve bürokratların keyfi uygulamaları olarak kayda geçmiştir. Sınırlı da olsa, bu imha uygulamalarının bir kısmı arşivcilik teorisi bakımından belli bir karakter ortaya koyabilecek durumdadır. Evrak imha uygulamaları hakkında bilinenlerin tamamından hareketle Osmanlı Devleti dönemi evrak imha uygulamasına ait genel bir karakter belirlemesi yapmak; böylelikle de, bu uygulamaların nasıl bir mesleki teoriye işaret ettiği konusuna açıklık kazandırmak mümkündür.

Osmanlı Devleti’nin ilk yıllarına ait yönetim evrakı hemen hemen günümüze ulaşmamıştır. Devlet Arşivleri Başkanlığının ve dönemin evrakına sahip diğer arşivlerin bu tür tarihsel evrakın bir kısmından yoksun oluşu bunu açıkça göstermektedir. Kuşkusuz bunun sebepleri araştırılmaya değer görünmektedir.

Osmanlı dönemi (1300-1922) evrakının tamamının günümüze kadar neden ulaşmadığı konusunda ilk akla gelen, bu evrakın günümüze ulaşmasına siyasî hadiselerin mani olduğudur. Nitekim bazı araştırmacılar, ilk dönem Osmanlı yönetim evrakının Moğol istilası (14021413) sırasında meydana gelen karmaşa ve yangın dolayısıyla Bursa'da yok olduğunu iddia etmektedirler (“Osmanlı Arşivi Tarihçesi”, 1990, s. 9; Akyıldız, 1995, s. 69). Halil İnalcık (1988, s. 294) ve Fahamettin Başar (1995, s. 480) ise bu dönem evrakının devletin hazinesi ile birlikte Yıldırım Bayezid'in (sal. 1389-1403) büyük oğlu Emir Süleyman (1413-1421) tarafından alınarak Edirne'ye nakledildiği bilgisini vermektedirler. Ancak Emir Süleyman idaresinde Edirne' deki ihya edilen kurumlar tarafından oluşturulan -ve büyük ihtimalle Edirne'ye taşınan ilk dönem- evrakının burada meydana gelen dîvânhâne yangını ve diğer yangınlar sebebiyle neredeyse tamamen yok olduğu bilinmektedir (“Osmanlı Arşivi Tarihçesi”, 1990, s. 9). ${ }^{10}$

Osmanlı bürokrasisinde -şimdilik bilinen- ilk evrak imha uygulaması Tanzimat Dönemi’nde gerçekleşmiştir. Devlet yönetiminin derin bir revizyondan geçtiği, idarî yapılanmada güçlü değişikliklerin planlandığı ve çeşitli ıslahatların hayata geçirildiği bu dönemde, kurumların örgütlenme şeklinde bazı yeni düzenlemeler yapılmış, diğer bazıları ortadan kaldırılmış ve yeni kurumlar ihdas edilmiştir (Findley, 1994; Akyıldız, 1993). Bütün bunlar yapılırken, bir taraftan da eski kurumlara ait evrakın ne yapılacağı bir sorun olarak gündeme gelmiş ve çözüm yolları aranmıştır. Nihayet bulunan çözümlerden birisi de, ilga edilen kurumlara ait evrakın imha edilmesidir.

10 Moğol istilası sırasında yaşanan Fetret devrinden (1403-1413) sonra devlet birliğinin yeniden kurulması ve ardına da hızlı bir şekilde Osmanlı yönetimi adına vergilerin eski topraklardan toplanması girişimine bakılacak olursa, bu doğru bir bilgidir. Zira kısa sürede vergi toplama işinin başlatılabilmesi, ancak -Edirne'ye taşınan ve bu sayede- elde mevcut olan kayıtlar sayesinde gerçekleşmiş olmalıdır. 
Sözü edilen ilk evrak imha uygulaması 1826 yılında ilga edilen yeniçeri ocağına ait evrakın imhasıdır. Dönemin Maliye Bakanı Safvetî Paşa, konuya esas teşkil eden ve uygulamaya konu olan mazbatasında (1261/1845) yeniçeri ocağına ait evrakın imha edilmesinin gerekçelerini şu şekilde açıklamaktadır:

[...] mülgâ ocaklara mütedâ'ir biraz evrâk ve defâtîr-i atîka ile cizye kâğgdları bulunarak bunların ba 'd-ezîn lüzûm ve iktizâsı olmayacağından ve hark ile ortadan kaldırılması münâsib göründüğünden îcâbının icrâsı husûsu nâzır-1 müşârun-ileyh hazretleri taraflarından istîzân ve inbâ kılınmış ve vâk1'â geçenlerde ba'zı evrâk-1 lâzıme taharrîsi zımnında hazîne-i merkûmeye Bâb-1 Alî’ den dahi me'mûr irsâliyle bir takım bî-lüzûm evrâk ve defâtîrin kesretinden dolayı evrâk-1 lâzımeye dest-res olunamamış ve o makûle bî-lüzûm evrâkın ilerüde iktizâsı olmayacağına nazaran ol vechle hark ve imhâsı yolunda görünmüş olmağın zikrolunan bî-lüzûm evrâk ve defâtîrin Sarây-1 Hümâyûn'da olan furunlarda ihrâk etdirilmesi [...] (BOA., İ. Dahiliye, 5152; BOA, Ayniyat Defteri, 769/51; BOA, Ayniyat Defteri, 770/29; Aktaş, 1985, s. 67; Belgelerle arşivcilik tarihimiz, 2000, ss. 271-273).

Bu mazbatada Safvetî Paşa, mülga (faaliyetine son verilen) ocaklara dair evrak ve defterler ile cizye ve hazine kâğıtlarının lüzumsuz olduğu gerekçesiyle saraydaki mevcut firınlarda yakılmasından, yani söz konusu evrakın artık idarî olarak yararlanılmayacak evrak grubundan olduğundan söz ederek firınlarda yakılmak suretiyle imha edilmesinden bahsetmektedir. Sonuçta, saklanmasına lüzum görülmeyen mülga yeniçeri ocağına ait bir takım evrak ve defterlerin saray fırınlarında imha edilmesi isteği münasip görülerek uygulamaya konulmuştur. Mazbata metni içinde üzerinde durulması gereken diğer bir imha uygulaması ise erişim güçlügü yaşanması sebebine bağlı olarak ortaya çıkmıştır ve yine ileride kullanılmayacağı (idarî olarak ihtiyaç duyulmayacağı) düşüncesiyle yine evrakın firınlarda yakılmak suretiyle imha edilmesidir (BOA., İ. Dahiliye, 5152; BOA, Ayniyat Defteri, 769/51; BOA, Ayniyat Defteri, 770/29; Aktaş, 1985, s. 67; Belgelerle arşivcilik tarihimiz, 2000, ss. 271-273).

Yukarıda anlatılan imha teşebbüsünü arşivcilik açısından ileride atılacak radikal ve modern adımların ilk işareti olarak değerlendirenler olmuştur (Belgelerle arşivcilik tarihimiz, 2000, s. 10). Ancak bu adımı, evrak imha uygulaması konusunda yeni ve anlamlı gelişmeler yaşanacağı şeklinde değil, aksine Osmanlı arşivlerinin korunması, depo şartlarının iyileştirilmesi ve düzenleme çalışmalarının daha kolay ve rahat bir şekilde yapılması gibi diğer meslekî konularda hayata geçirilecek adımların habercisi olarak görmek gerekmektedir. Zaten Hazîne-i Evrak'ın kurulması, burada -ve daha başka kurumlarda- düzenleme çalışmalarının yapılması, hatta Bâbıâli Evrak Odası'nın kurulması gibi sonraki yıllara ait gelişmeler de bunu açık bir şekilde teyit etmektedir. 
Safvetî Paşa'nın konuya esas olan mazbatasından, depolarda aşırı biriken evrak nedeniyle erişimin güçleştiği, hatta imkânsız hale geldiği; bu sebeple de, ileride lazım olmayacağı düşüncesiyle yeniçeri ocağına ait bazı evrak ve defter ile başka bir idarî işleme dayanak olması bakımından aranan evrakın ihtiyaç duyulmayacak birtakım evrak yüzünden depoda bulunamaması nedeniyle gereksiz (idarî bakımdan ihtiyaç duyulmayacak) evrakın yakılmak suretiyle imhası yoluna gidilmek istendiği açık bir şekilde anlaşılmaktadır. Başka bir ifadeyle, gerçekleştirilecek bir imha uygulamasının, depoların boşalmasıyla birlikte geri kalan evraka erişimde kolaylık sağlayacağı düşünülmüştür. Burada asıl önemli olan ise bu evrakın "neden artık lazım olmayacağı" düşüncesinin dayandırıldığı bakış açısıdır. Konu daha ayrıntılı bir şekilde ele alınacak olursa, bu evrak ve defterlerin -genellikle bürokratik işlemlere, kararlara ve malî denetimlere, hatta yasal haklara dayanak teşkil etmesi bakımından korunması nedeniyle- varlığı, dolayısıyla fonksiyonlarına dayalı işlemlerine son verilen bir kurumun evrak ve defterine artık ihtiyaç duyulmadığı ve bu sebeple de imhası yoluna gidildiği söylenebilir. Yine idarî bakımdan işe yaramaz değerlendirmesi yapılmış olan başka bir takım evrakın da -bu hadiseden biraz önce- imhası yoluna gidilmiştir. Aynı belgede işlemlere dayanak teşkil edebileceği düşünülen/ böyle bir ihtimalin söz konusu olduğu evrak için benzer bir kararın alınmamış olması da bunu -bir bakıma- dolaylı olarak teyit etmektedir. Yani evrakın imha düşüncesinin şekillenişinde, mevcut evrakın ileride kullanılma ihtimali (yani kullanılma ihtimalinin olmaması) ve muhtemel bazı söylentilerin daha başlangıçta bertaraf edilmesi düşüncesi göz ardı edilmemiştir (BOA., İ. Dahiliye, 5152; Aktaş, 1985, ss. 67-72; Belgelerle arşivcilik tarihimiz, 2000, ss. 271-273). Nitekim aynı belgede;

[...] bunlardan başka bir takım fersûde evrâk zuhûruyla anlardan hiç bir vakitde istifâde kâbil değil ise de şâyed ilerüde lüzûmu olur ya'ni ba'zı evrâk-1 mühimme derûnunda kalmış idi, telef oldu denilür mütâla'asıyla başkaca mahalle konulmuş [...] (BOA., İ. Dahiliye, 5152; Belgelerle arşivcilik tarihimiz, 2000, s. 271-273; Aktaş, 1985, ss. 67-72; Aktaş, 2000, ss. 379-387).

şeklinde geçen ifade duruma üstü kapalı bir şekilde açıklık getirmektedir.

Bu noktada tartışılması gerekli konulardan birisi de, söz konusu evrakın neden yakıldığı, daha doğrusu -daha sonraki uygulamalarda görüldüğü gibi- farklı amaçlarla kullanılması yoluna gidilmediğidir. Bunun tek nedeni, herhalde Yeniçerilerin gücünde yatıyor olabilir. Yani kısa zaman içinde yaşanabilecek bir genel devlet zaafı ile birlikte mevcut evraktan hareketle bu kurumun yeniden ihya edilebileceği düşüncesi olabilir.

Evrak imha uygulamasıyla ilgili başka bir örnek de, 1267/1851 tarihinde imha edilmek istenen cizye evrakıyla alakalıdır. Bu konu, söz konusu evrakın yakılmak yerine fabrikalarda kullandırılması, ciltçilere verilerek mukavva yapılması veya fişek yapımında değerlendirilmesi münasebetiyle gündeme gelmiş; sonuçta Maliye Hazinesi'nde korunan 1848-1850 yıllarına ait 
cizye evrakıyla esnaf tezkiresi gibi geçmiş senelere ait "lüzumsuz" evrakın yakılmayıp tekrar kullanılmak üzere matbaaya teslim edilmesine karar verilmiştir. Bu imha uygulaması sırasında 1265-1266 (1848-1850) yıllarına ait evrakın gayrimüslim reayadan (halktan) cizye toplanması sırasında kullanılacağı belirtilerek, ancak geri kalanların imhasına müsaade edilmiştir (BOA., İ. Meclis-i Vâlâ, 6536; Belgelerle arşivcilik tarihimiz, 2000, ss. 182-185). İşlemlerde yararlılı̆̆1 olmayacak evrakın imhasına müsaade edildiği; işlemlerde kullanılacağı değerlendirilen kayıtların ise korunması yoluna gidildiği bu yazışmadan dolaylı olarak anlaşılmaktadır.

Bu konunun anlatıldığı yazışma şu şekilde devam etmiştir:

Hazîne-i Celîle'de mahfûz altmış beş ve [almış] altı senelerinden [1265-1266] mâ'adâ sinîn-i atîka cizye evrâkıyla esnâf tezkiresi vesâ'ire misillü bî-lüzûm evrâkın emsâl-i mesbûkası vechle [...] evrâk-1 mezkûre ihrâk etdirilmekden ise fabrikalara verilerek kullandırılması ve yâhûd mukavvâlara vesâ'ire kullanılmak üzere mücellidlere veya fişenk bağlatdırılmak üzere Harbiye'ye verilmesi [...] (BOA., İ. Meclis-i Vâlâ, 6536; Belgelerle arşivcilik tarihimiz, 2000, ss. 182-185).

Yine ilgili yazışmada;

[...] elli sekiz senesinden altmış altı senesi gâyetine kadar [...] evrâk Hazîne-i Celîle'de hıfz etdirilmiş ise de altmış yedi senesi Muharremi gurresinden i'tibâren cizyenin bilâ-evrâk an cemâ'atin istihsâli sırasında altmış beş ve [almış] altı senelerinde cizyesini te'diye etmeyen re‘âyâ cizyesinin dahi tahsîli muktezâ-y1 irâde-i seniyyeden bulunduğu cihetle seneteyn-i mezkûreteyn cizye evrâkından mâ‘adâ gerü seneler evrâkının ve esnâf tezkiresi vesâ'ire misillü bî-lüzûm evrâk emsâl-i mesbûkası vechle hark etdirilmesi husûsu [...]

dile getirilerek, işlemlerde yararlılığı olmayacak evrakın imhasına müsaade edildiği anlaşılmaktadır.

Diğer bir evrak imha uygulamasına 8 Ekim 1903 tarihli bir vesikada rastlanmaktadır. Bu örnekte, Sıhhiye Nezâreti'nde biriken battal ve eski evrakın teşkil olunan bir komisyon tarafından incelenerek, içerisinde lâzım olabilecek evrakın olmadığının anlaşıldığından ve eski patent ve tezkire koçanlarından ibaret olduğu anlaşılan bu evrakın tayin olunacak özel bir memur tarafindan Kavak Karantinahanesi'ne sevk olunup yetkililerin huzurunda yakılmasından ve bunun da Sıhhiye Meclisi tarafindan uygun bulunduğundan söz edilmektedir (BOA., Y. MTV., 252/64; Belgelerle arşivcilik tarihimiz, 2000, s. 436). Bu belgede geçen;

İdâre-i Sihhiyye>de bir müddetden berü terâküm etmiş olan battal evrâk-1 atîka hakkında Meclis-i Umûr-1 Sıhhiye a'zâsından Said Beyefendi ile Belçika delegesi Baron de Hobeş [Baron de Hübsch]'den mürekkeb teşkîl kılınan komisyon 
ma'rifetiyle tedkîkât-1 lâzıme bi’l-icrâ bunların sefâ'ine verilüp hükmü geçmesine mebnî istirdâd edilmiş bulunan atîk ve battal patenta ile tezâkir koçanlarından ibâret olarak ihticâca sâlih evrâkdan olmadığı anlaşılmış bulunduğundan [...] (BOA., Y. MTV., 252/64; Belgelerle arşivcilik tarihimiz, 2000, s. 436)

şeklindeki ifade, imha uygulamasının, söz konusu evrakın ihtiyaç duyulmayacak evrak sınıfından kabul edilmiş olmasından dolayı gerçekleştirildiğini göstermektedir. Ancak yine de bu bakış açısı -gerekçesi net olmadığından- üstü kapalı bir şekilde verilmiştir; dolayısıyla, gerekçenin nedenini açık bir şekilde bilmemiz maalesef söz konusu değildir. Bununla birlikte, sonraki işlemlerde kullanılma değer ve ihtimali bulunmayan evrakın imhası yoluna gidildiği üzerinde durulabilir.

Evrak imhası konusunda en bilinen örneklerden birisi de, II. Abdülhamid döneminde oluşturulan istihbarat jurnallerinin imha edilmesi meselesidir. II. Abdülhamid'in tahttan indirilmesinden sonra bu jurnaller, ${ }^{11}$ Yıldız Sarayı'nın tasfiyesi sırasında bir araya getirtilerek tasnif edilmek istenmiştir. Bu sırada yapılan bir değerlendirmede, söz konusu evrakın Osmanlı tarihine 1şık tutacak nitelikte olduğu dile getirilmiştir. Ancak Hareket Ordusu Komutanı Mahmud Şevket Paşa'nın (1856-1913) bir telgrafiyla jurnaller Harbiye Nezâreti'ne getirtilmiş; burada yapılan tasnif sırasında, bu jurnallerin içlerinde İttihat ve Terakki mensuplarının yanı sıra II. Abdülhamid'in hal'inde (tahttan indirilmesinde) belirleyici olan bazı zevata ait jurnallerin bulunduğu anlaşılmış ve bu durum rahatsızlıklara sebebiyet vermiştir. Sonuçta, bu jurnaller, Harbiye Nezâreti bahçesinde -bir söylentiye göre Harbiye Nâzırı Enver Paşa'nın (1881-1922) emriyle- bir gece yakılmak suretiyle imha edilmiştir (Tugay, 1935, s. 17; Uşaklıgil, 1942, s. 28; Demiroğlu, 1955, s. 37; İnal, 1964, s. 2100; Yalçın, 2000, s. 215; Beyhan, 2002, ss. 940-945; Candemir, 2011, ss. 38-39). Tarihçiler için spekülasyon alanlarından biri olan bu jurnallerin imha edilmesiyle ilgili emrin kim tarafından verildiğinin bile belli olmadığını iddia edenlerin bulunduğu bu uygulamanın gerekçelendirilmiş olmadığını tahmin etmek herhalde zor değildir. Zaten şimdiye kadar bu yönde ortaya çıkan bir bilgi de bulunmamaktadır. Ancak burada üzerinde durulması gereken asıl hususun, yeni yönetimin ihyasına çalışan şahısların jurnaller dolayısıyla ortaya çıkabilecek bilgiden zarar görebilecek olma ihtimalinin yanı sıra, hafiye (istihbarat) teşkilatının artık eski görev sahasının bulunmaması, yani artık eski idarî etkisinin hiçbir şekilde söz konusu olmamasıdır. Bu nedenle, -kurumun ilga edilişinden dolayı- burada da işlemlere dayanak teşkil etmeyecek evraktan söz edilebilir ki bu da, evrakın imhasına karar verilmesinde etkili olmuş olabilir.

Bu örneklerden başka diğer önemli bir evrak imha uygulaması da 20. yüzyılın ilk çeyreğinde gerçekleştirilmiştir. Bu durum Osmanlı Devleti’nde bir arşivcilik uygulaması olarak evrak

11 Bu jurnaller, II. Abdülhamid döneminde Zabtiye Nezareti’ne bağlı Hafiyye Teşkilatı tarafından hem iç hem de dış aktörlerin rol aldıkları Osmanlı Devleti'ne yönelik yıkıcı faaliyetlerin yanı sıra komşu coğrafyalarda meydana gelen siyasî değişimler ve bu değişimlerin doğurduğu/doğuracağı problemlerin öğrenilmesi ve önünün alınması nedenlerine bağlı olarak düzenlenmiştir (Beyhan, 2002, s. 940). 
imhasına ait düşüncenin 20. yüzyılın başlarında teşekkül ettiğini göstermesi bakımından önemlidir. Bu teşebbüse neden ise Tanzimat'tan sonra ortaya çıkan ve -aradan geçen zamana rağmen- muhtemelen kamu çalışanlarının henüz tam olarak alışamadıkları modern bürokratik usullerin sebep olduğu hızlı evrak artışıdır. Hızlı evrak üretimi -İkinci Dünya Savaşı yılları ile karşılaştıramayacak derecede olsa da- Birinci Dünya Savaşı (1914-1918) dolayısıyla had safhaya ulaşmıştır. Bu hızlı evrak artışı neticesinde arşiv depolarında yığılı kalan evrak, bir tasfiye düşüncesinin doğmasına gerekçe oluşturmuştur. Yapılan bir çalışma neticesinde de, Osmanlı Devleti'nde 1334 (1917) tarihli evrak muhafaza ve imhasına ait ilk nizamnâme neşredilmiştir (Aydın, 1999, s. 48).

Osmanlı Devleti’nde evrak imhasıyla ilgili ilk nizamnâmenin hazırlanması Posta ve Telgraf Nezareti'nde biriken evrakın satılması konusu münasebetiyle gündeme gelmiş ve bu konunun çeşitli kurumlar nezdinde görüşülmesi sonucunda bir nizamnâmenin hazırlanması gerçekleşmiştir. Aslında bir nizamnâme hazırlanmasının nedeni konu hakkında "standart bir uygulama prosedürü” geliştirmektir. $\mathrm{O}$ ana kadar çeşitli kamu kurumları tarafından yapılan imha uygulamalarının keyfiyet içerdiği üzerinde durulmamış olsa da, en azından muntazam yapılmadığı ve her dairenin konu hakkında ayrı ayrı kararlar aldıkları açık bir şekilde ifade edilmiştir (BOA. DUİT., 37-2/11-6; Belgelerle arşivcilik tarihimiz, 2000, s. 361). Belgede, “[...] Emlâk-1 Emîriyye Müdîriyet-i Umûmiyyesi'nin mezkûresinde ise bi'l-hâssa devâ'irce bu bâbda muntazam bir usûl ta 'kîb edilmeyüp her dâ'ire kendi ictihâdına göre hareket etmekde olduğu tahkîkât-1 vâk1 'adan anlaşılmış olduğundan [...]” (BOA. DUİT., 37-2/11-6; Belgelerle arşivcilik tarihimiz, 2000, s. 361) şeklinde geçen ifade de bunu açıkça ortaya koymaktadır. Ayrıca imha süreleri belirlenmiş evrakın, bu süre sonunda imha edilebileceği, ancak bir ihtilaf ve dava konusu haline gelen evrakın ise -imha süreleri dolmuş olsa bile- süre sonunda imha edilmeyeceği üzerinde durulmuştur (BOA. DUİT., 37-2/11-6; Belgelerle arşivcilik tarihimiz, 2000, s. 362). Bu da, belgede, “[...] mu'ayyen müddetlerin inkızâsından sonra der-dest-i fasl ve rü’yet bir ihtilâf veyâ da 'vâya ta 'alluk etmedikce elden çıkarılmasında mahzûr olmayacağı [...]” (BOA. DUIT., 37-2/11-6; Belgelerle arşivcilik tarihimiz, 2000, s. 362) şeklinde anlatılmıştır. ${ }^{12}$ Söz konusu yazışmada, ayrıca evrakın imhasına kimin karar vereceği, belirlenen süre sonunda evrakın imhasının ortaya herhangi bir mahzur çıkarma ihtimalinin olup-olmadığ 1 ve yaşanacak olumsuzluklar hakkında kimlerin sorumlu tutulacağı da değerlendirilmiştir (BOA. DUIT., 372/11-6; Belgelerle arşivcilik tarihimiz, 2000, s. 362). Bu da, söz konusu evrakta,

[...] bu mes'elede asıl nazar-1 dikkate alınmak lâzım gelen cihet o nev' evrâk-1 atîkadır deyü imhâ olunmak üzre tefrîk edilen evrâk miyânında başka bir şey veya

12 Bu bilginin; 2018 yılında yürürlüğe giren 11 numaralı Devlet Arşivleri Başkanlığı Hakkında Cumhurbaşkanlığı Kararnamesi (m. 4/a) ile uyumlu bir bakış açısına sahip olması anlamlıdır. İlgili maddede arşiv belgesi için yapılan tanımsal açıklama şu şekildedir: "Arşiv belgesi: Son işlem tarihi üzerinden yirmi yıl geçmiş veya üzerinden on beş yıl geçtikten sonra kesin sonuca bağlanmış olup da işlevi bulunmayan, varsa tâbi olduğu mevzuattaki saklama sürelerini tamamlaması nedeniyle Devlet Arşivleri Başkanlığına devredilmesi gereken belgeyi." 
der-dest-i fasl ve rü’yet bir ihtilâf ve da'vâya müte‘allik olanlar bulunmadiğını kimler tasdîk edüp aks-i hâlin mes’ûliyyeti kimlere terettüb edeceğinin ta'yîninde olduğuna nazaran bir müddet-i mu'ayyenenin hitâmında elden çıkarılması mümkün olan evrâkın nev‘ ve müddet i'tibârıyla ta'yîninden evvel bu bâbda tatbîki lâzım gelecek olan ahkâm-1 umûmiyyenin bir nizâmnâme ile ta'yînine lüzûm görülmüşdür. (BOA. DUIT., 37-2/11-6; Belgelerle arşivcilik tarihimiz, 2000, s. 362).

şeklinde açıklanmıştır.

\section{3. İmha Uygulamasına İliş̧kin Nizamname Çalışması}

\subsection{Nizamnâme Lâyihasının İçeriğine Dair}

Osmanlı İmparatorluğu'nun hüküm sürdüğü yüzyıllar boyunca faaliyet gösteren kurumları tarafından -günümüz evrak üretim hızı ile kıyas kabul etmese de- yoğun şekilde üretilen evrakın kontrolünün, korunmasının ve erişiminin soruna dönüştüğü zamanlarda çözüm arayışları gündeme gelmiştir. Çözüm arayışları bakımından önem arz eden gelişmelerden birisi bütün Osmanlı kurumları için düşünülen nizamname çalışmasıdır. Söz konusu nizamnamenin hazırlanması işiyle Islahat-1 Maliye Komisyonu ilgilenmiştir. Islahat-1 Maliye Komisyonu, tartışılan konuları dikkate alarak, Hazine-i Evrak Teşkîlât Kânûnu Layihası'na göre, hükumet dairelerinde bulunan evrak ve defterlerin saklanma süresine, saklanacak olanların cinsine, elden çıkarılması gerekenler hakkında ne şekilde işlem yapılacağına dair Posta ve Telgraf Nezareti'ne ait altı maddelik bir nizamnâme layihası hazırlamıştır (BOA. DUIT. 37-2/11-6; Belgelerle arşivcilik tarihimiz, 2000, ss. 362-365). Posta ve Telgraf Nezareti, imhayla ilgili taleplerinin gerekçesini, idarî ve hukukî yönden gerekli olmayan evrakın muhafazasının lüzumsuz masraflara yol açması ve geriye yönelik işlemlerin yürütülmesinde ve bu sebeple evrakın aranılmasında güçlükler çıkarması olarak göstermiştir. Bu durum, ilgili yazıda şu şekilde ifade edilmiştir:

[...] Posta ve Telgraf Nezâretince maksûd olan gâye mürûr-1 zamânla gerek idâre nokta-i nazarından gerek posta ve telgrafla mu'âmelesi olan eşhâsın tevsîk ve tebyîn-i hukûku cihetinden bir gûne lüzûmu kalmamış olan evrâkın hıfzına devâm edilmesi idâre içün bî-lüzûm masârifi ve azîm müşkîlâtı dâ‘î bulunduğu cihetle bu gibi evrâkın münâsib bir sûretle elden çıkarılmasından ibâret bulunmuşdur.

Bununla birlikte sonraki zamanlarda ihtiyaç duyulacak evrakın imha edilebilme ihtimalinin ve tehlikesinin de olduğu göz ardı edilmemiştir. Bu durum, ilgili yazışmada "evrâk ve kuyûd-1 resmîyede yirmi otuz ve belki elli sene sonra bile lâzım olacakları bulunabileceği”" şeklinde ifade edilmiştir. Bu durumun ise ancak bir imha listesinin hazırlanması ve bunun da kanun ve nizamnameler hazırlanmak suretiyle çözüme kavuşturulması gerektiği belirtilmiştir. Bu da, "mahzenlerde hıfzı lâzım gelüb ancak ne gibi evrâkın kaç sene sonra imhâ edilebileceğine dâ'ir kavânîn ve nizâmât tanzîm edilerek ana göre hareket edilmek münâsib olacağı” ifadesi ile karşılık bulmuştur. 
İlgili yazışmada; kurumlarca üretilen evrakın neden korunduğuna işaret eden ve günümüzde de geçerli olan iki nokta üzerinde durulduğu oldukça açıktır:

1. Belgenin işlemlere dayanak olarak kullanıldığını ortaya koyan idarî değer (ki bu değeri “işlemlere" ve “denetim” süreçlerine dayanak teşkil etme şeklinde) anlamak mümkündür.

2. Belgenin şahısların ve kurumların haklarının muhafazasında kullanıldı̆̆ını ifade eden hukukî değer.

Bu her iki değere sahip olmadığına kanaat getirilen evrakın ise lüzumsuz olduğu kararlaştırılmış ve korunmasına devam edilmesinin gereksiz masrafa ve depodaki belgelerin araştırılmasının -muhtemelen belgelerin oluşturduğu yığınlar, bunun oluşturduğu mevcut düzensizlik ve erişim güçlüğü nedeniyle- büyük zorluklara yol açacağ üzerinde durulmuştur.

Posta ve Telgraf Nezareti'ne ait biriken evrakın imhasına dayanak teşkil eden bu gerekçeler, Hazine-i Hukuk Müşavirliği tarafından değerlendirilmiştir. Bu değerlendirme sonucunda, Hazine Hukuk Müşavirliği dört temel nokta üzerinde durmuştur. Bu noktalar;

1. Resmi kayıtlarda yirmi, otuz ve belki elli sene sonra bile lâzım olabilecek evrakların bulunabileceği,

2. Evrakın teker teker tetkik edilmedikçe hangisinin elden çıkarılmasında mahzur olacağı hakkında bir görüş bildirmenin mümkün olmayacağ1,

3. Posta evrakının da diğer dairelerdeki gibi mahzenlerde muhafaza edilmesi gerekeceği,

4. Hangi evrakın kaç sene sonra imha edilebileceğine dair kanun ve nizamların tanzim edilerek ona göre hareket edilmesinin münasip olacağı.

şeklinde açıklanmıştır. Dikkat edileceği üzere, burada açıklanan maddeler, aranacak evrakın bulunması, imha edilecek evrakın iyi bir araştırmadan (değerlendirme işleminden) sonra belirlenmesi, posta işlerine ait ve diğerlerine göre daha önemsiz kabul edilebilecek olan belgelerin bile arşiv mahzenlerinde -korunmaları nedeniyle- yer işgal edeceği, evrakın korunma şekli ve kurumlara özel saklama planlarının tespiti şeklindedir. Bütün bunların günümüzde de yapılması gerekli önemli meslekî uygulamalar arasında yer aldığı açıktır.

\subsection{Nizamname Layihası Maddelerinin Değerlendirilmesi}

\subsubsection{Korunacak Evrakın Gruplandırılması}

Korunma nedenlerine göre evrakın gruplandırılması söz konusu nizamnâme lâyihasının (BOA. DUİT., 37-2/11-6; Belgelerle arşivcilik tarihimiz, 2000, ss. 362-365; Aydın, 1999, ss. 51-53) ilk maddesinde açıklanmıştır. Buna göre resmi kurumlarca üretilen evrak ve defter 
muhafaza bakımından beş ayrı gruba ayrılacak ve bunların önem derecelerine göre saklama süreleri tespit edilecektir. Beş gruba ayrılan evrak ve defter konuları şu şekilde zikredilmiştir:

1. Bütün kânun, nizamname ve talimatnameler ile yabancı devletlerle yapılan anlaşmalar ve bu anlaşmalar süresince cereyan eden haberleşme ve görüşmelere ilişkin evrak,

2. İmtiyazlı şirketlerin tesisine ait fermanlar ile şartname, mukavelename ve nizamnameler, maden fermanları, arkeolojik kazı izinleri, patentler, (ihtira beratları) anonim veya kooperatif türü şirketlerin kuruluş izin belgeleri, inşaat sözleşmeleri,

3. Mahkeme ve noter kayıtları, nüfus, askerlik ve memuriyet sicilleri, hususi mektepler ile dini ve hayır amaçlı tesisler ve özel izni gerektiren hususi teşekküllere ait tesis izinleri,

4. Belirli bir zaman içerisinde tetkik ve tasdiki gereken harcama ve hesaplara ait evrak,

5. Muamelesi devam etmekte olan işlere ait evrak.

\subsection{2. İmhasında Sakınca Görülen ve İmhası Yasaklanan Evrak}

Nizamnâme lâyihasının ikinci maddesi, imhasında sakınca görülen ve imhası yasaklanan evrak ve defterlerle ilgilidir. Buna göre; birinci maddede sayılan ilk üç sınıf evrakın imha edilmek üzere satışı, yakılması veya başka bir yolla imhası yasaklanmakta ve kanun, nizamnâme, talimatnâme, anlaşma, sözleşme, mezuniyet belgeleri ve fermanların asıllarının günü gününe Hazine-i Evrak’a gönderilmesi ve dairelerde bu tür evrakın yalnız tasdikli suretlerinin veya matbularının muhafaza edilmesi istenmektedir. Yine aynı maddede; üçüncü sınıfta yer alan evrak ve sicillerin, onları üreten daireler tarafından muhafaza edilmesi ve zamanla ihtiyaç duyulmayanların yine daireleri tarafından ayrılarak Hazine-i Evrak'a devir ve teslim edilmesi gerektiği belirtilmektedir.

\subsection{3. İkinci Madde Hükümlerine Tabi Olacak Evrak}

Nizamnâme lâyihasının üçüncü maddesi; -yukarıda ifade edilen- dördüncü sınıfa giren evrak arasından birinci ve üçüncü sınıf evrak grubundan sayılanların ikinci madde hükümlerine tabi olacağını bildirmekte ve bunların tasdikli suretlerinin muhafazasını istemektedir.

\subsubsection{Dördüncü Sınıfa Dâhil Edilen Evrakın ve Saklama Sürelerinin Tespiti}

Nizamnâme lâyihasının dördüncü maddesi dördüncü sınıfa dâhil olan evrakın tespitiyle, -yasalar da dikkate alınarak- bunların saklama sürelerinin belirlenmesiyle ve ihtilafın yanı sıra herhangi bir davaya konu olan evrakın muhafaza edilmesiyle ilgilidir. Buna göre; dördüncü sınıfa dâhil edilen evrakın her dairede ayrı ayrı tespit edilmesi ve tespit edilen serilerin kanunlar ve nizamnâmeler gereğince ne kadar saklanması gerektiğinin belirtilmesi istenmekte, ayrıca süresi dolan evrak arasında herhangi bir ihtilaf ve dava sebebiyle elde tutulması gerekenlerin muhafazası, bunların dışındakilerin ise imha edilebileceği belirtilmektedir. 


\subsubsection{Bir İhtilafa ve Davaya Konu Olan Evrak}

Nizamnâme lâyihasının beşinci maddesine; bir ihtilafa ve davaya konu olan evrakın, ihtilaf ve dava nedeniyle dosyasından alındıktan sonra, bu evrakın dosyadaki yerlerine bir ödünç fişinin konulmasıyla ilgilidir. Buna göre; Hazine-i Evrak’a gönderilecek olan evrakın dışında kalan evraktan ihtilaf ve dava dolayısıyla serilerinden çıkarılanların yerine bir ilmühaber (vekil fişi, çıkış kaydı) konulacak ve çıkarılan evrak ilgili dava dosyasına yerleştirilecektir.

\subsubsection{Evrakın İmha Şekli}

Nizamnâme lâyihasının altıncı maddesi, evrakın ne suretle imha edilmesi gerektiğini oldukça açık bir şekilde belirlemektedir. Bu maddeye göre evrak ya okunamayacak bir şekilde kestirilerek/kıyılarak satılacak ya da yakılarak imha edilecektir. Bu noktada evrakın kitap cilt kapaklarında veya fişenk yapımında kullanılması için ayrılması üzerinde durulmaması dikkat çekicidir. Evrakın içerdiği kamusal/kurumsal/resmî bilginin hassasiyetinden olsa gerektir ki evrak imhasının günümüzdeki gibi bir işlem sonucunda gerçekleştirilmesi tercih edilmiştir.

\section{Evrakın Tasfiyesi ve Ayıklama-İmha Komisyonu Kurulması}

Diğer yandan, kurumlarda oluşan evrakın imha süreçleri de önemli bir konudur. Zira eldeki evrakın koruma sürelerinin ihtiyaçlar doğrultusunda belirlenmesi ve ihtiyaçlar ortadan kalktıktan sonra imhası belli bir plan dâhilinde yapılmak durumundadır. Aslında bütün bunlar 1327-1330 (1911-1914) yılları arasında İstanbul'da kamuya ait çeşitli evrak mahzenlerinde birikmiş belgelerin ayrılması ve imhası konusunda çeşitli sorunlar yaşanmasıyla gündeme gelmiştir (Osman Nuri ve Mehmed Hayati, 1332; Binark, 1980/b, s. 75; Rukancı ve Anameriç, 2006, ss. 96-110). Posta ve Telgraf Nezâreti için hazırlanan nizamnâme lâyihasında yığılmalara ve farklı uygulamalara temas edilerek, her dairenin kendine has uygulamalarının olduğu, bu yüzden de hangi evrakın ne kadar süre ile saklanmasının uygun olacağının belirlenmesi ve bunun standart bir uygulama haline dönüşmesinin sağlanması gerekliliği üzerinde durulmuştur.

Konuyla ilgili gelişmelerden birisi de, 1914 yılında "Evrâk-1 Atîkanın Sûret-i Tasfiyesine Dair Rapor" (değerlendirilmesi ve metni için bkz. Rukancı ve Anameriç, 2006, ss. 91-110) adıyla bir raporun düzenlenmiş olmasıdır. Şehremâneti Me'mûrin Kalemi Müdürü Mehmed Hayati ile Şehremaneti Hazine-i Evrâk Başkâtibi Osman Nuri tarafından kaleme alınan Rapor'da, o dönemde resmi belgelerin nerelerde ve hangi şartlarda korunduğu gibi farklı konuların yanı sıra, söz konusu belgelerin tasfiye işlemleri ayrıntılı olarak ele alınmıştır. Bu rapor, daha sonra hazırlanacak olan nizamnâmenin belirlediği içerikle paralellik arz etmektedir. Hatırlanacağı üzere, söz konusu nizamnâmeye göre evrakın dört gruba ayrılması bu raporda ana hatlarıyla dikkatlere sunulmuştur. Raporda, muhafaza edilmek üzere ayrılan evrak ile imha edilecek evrak arasındaki ayrıma bakılacak olursa, bunun açıkça gözetilmiş olduğu söylenebilir. Örneğin; söz konusu raporda, bu tarihten çok sonra Theodore R. Schellenberg'in evrakın 
korunmasında önemli konular olarak belirlediği temel noktalara, yani korunmak üzere ayrılan evrakın değerini ortaya koyan "eşsizlik", "kullanılabilirlik", "form” ve "içerdikleri bilginin önemi” (Schellenberg, 1985, s. 269-279; Schellenberg, 2008, ss. 55-70) ilkelerine dikkat edilmiş olması nedeniyle, "kişilere", "nesnelere" ve "olaylara" ilişkin kayıtların korunması yönünde bir eğilim olduğu açıktır.

Bu komisyon raporunda belirtildiği gibi, zor şartlarda yürütülen ayırma çalışmalarının çok da başarılı bir şekilde yürümediği iddia edilebilir. Yaklaşı üç sene sonra bile imha komisyonu kurulması yönündeki yazışmada her dairenin halen kendine özgü ayırma ve imha uygulamaları ortaya koy(a)madıkları anlaşıılmaktadır. Bu durum; ilgili yazışmada -1917 yılına kadar- böyle bir ihtiyaca cevap olması bakımından ayrı bir çalışma yapılmadığı, bu konuyu ele alacak bir komisyon teşkil edilmesinin gerektiğinin ifade edilmesinden anlaşılmaktadır.

Belirtildiği üzere, bu komisyonun temel görevi kurumlara has saklama planları hazırlamak olacaktı. Bir imha komisyonu kurulmasına ilişkin yazışmada, devlet dairelerinde kullanılan evrak ve defterlerden saklanması ve imha edilmesi gerekenler hakkında elde kesin bir talimat ve karar bulunmadığından, bu konuda, her dairenin imha uygulaması bakımından kendi başına hareket ettiği, bunun ise saklanması gereken evrakın yanlış değerlendirme ve anlayış sebebiyle imha edilmesi ihtimalini beraberinde getireceği dile getirildikten sonra, bu tür yanlışlıklara meydan verilmemesi için Muhâsebe-i Umûmiyye Müdüriyeti merkez daireleri ile Dîvân-1 Muhâsebât memurlarından oluşan bir imha komisyonu kurulması gerekliliği üzerinde durulmuştur (BOA. BEO., 335986; Belgelerle arşivcilik tarihimiz, 2000, ss. 380-381). Konu, bu yazışmada şu şekilde ifade edilmiştir:

[...] devâ'ir-i devletde müsta'mel defâtir ve evrâk-1 müsbiteden muhâfazası îcâb edenler ile ihrâk ve imhâsı lâzım gelenler hakkında elde sarîh ve kat'î bir ta'lîmât ve mukarrerât mevcûd olmamasına binâ'en her dâ'irece husûsî karârlar ittihâzıyla ba'z1 evrâk ve defâtirin imhâ edilmekde olduğu cereyân-1 muhâbereden anlaşılmış ve evrâk-1 mebhûseden muhâfazası lâzım gelenlerin yanlış takdîr ve telakkî sebebiyle imhâsı cihetine gidilerek bu yüzden hukûk-1 hazînenin dûçâr-1 zıyâ‘ olması melhûz bulunmuş olduğundan âtiyen bu gibi ahvâl hudûsuna mahall bırakılmamak üzere Muhâsebe-i Umûmiyye Müdîriyet-i Umûmiyyesinin devâ'ir-i merkeziyye ve Dîvân-1 Muhâsebât me'mûrîninden mürekkeb olarak bir komisyon teşkîli tensîb edilmiş olmağla mezkûr komisyona birer me'mûrun ta 'yîn ve i'zâmı içün devâ'ir-i merkeziyyeye teblîgât-ı mukteziyye îfâsına [...]. (BOA. BEO., 335986; Belgelerle arşivcilik tarihimiz, 2000, ss. 380-381).

Ancak böyle bir çalışma içinde sorumluluk üstlenecek olan görevlilerin hangi kurumlardan tercih edilmesi ve nasıl bir niteliğe sahip olması gerektiği burada anlatılmamıştır. 


\section{Uygulamaların ve Nizamnâme Lâyihasının Arşivsel İmha Teorisiyle İlişkisi}

Gerek uygulamalardan gerekse hazırlanmaya çalışılan nizamnamelerden hareketle Osmanlı imha uygulamasının belli bir altyapısının mevcut olduğu ve bu altyapının da -önemli ölçüdebilimsel bir bakış açısı sunduğu rahatlıkla söylenebilir. Ayrıca imha uygulamasının bilimsel bir temele dayandırılması düşüncesi örneklerle temellendirilebilir. Osmanlı imha uygulaması, mevcut örneklerden ve bilinenlerden hareketle şu şekilde açıklanabilir:

Öncelikle Osmanlı dönemi imha uygulamalarının iki temel karakterinin olduğu söylenebilir. Bunlar; evrakın kasıtlı olarak ve herhangi bir kaygı gütmeksizin imhası ile daha sonra kullanma kaygısını içeren imha uygulamasıdır. Bunlar şu şekilde açıklanabilir:

1. Evrakın kasitlı olarak imha edilmesi: Evrakın bir kasit sonucu yok edilmesi, onların sonraki dönemlerde kullanılma ihtimalinin göz ardı edildiği uygulamalardır. Bu tür uygulamaların arşivcilik teorisi bakımından herhangi bir kıymeti bulunmamaktadır. Bununla amaç, uygulamaların arşiv anlayış ve teorisine uygun olmamaları nedeniyle, mevcut evrakın sadece yok edilmesidir. Bu uygulamaları hayata geçirenlerin, artık bir kültürel miras olarak kabul edilen arşiv belgelerinin gelecek nesillere aktarılması bakımından büyük ihmal gösterdikleri, hatta sonraki nesillerin geçmiş kültürleri öğrenme ve aktarma hakkına kast ettikleri söylenebilir. II. Abdülhamid dönemi jurnallerinin imhası bu türden bir uygulamaya verilebilecek oldukça net bir örnektir. II. Abdülhamid dönemini sona erdiren ittilalin önde aktörlerinin bile II. Abdülhamid'e jurnal sunduklarının anlaşılması ve ihtilal aktörlerinin birbirleri aleyhinde kullandıkları ifadelerin açığa çıkma endişesi, söz konusu jurnallerin imhası kararının verilmesinde etkili olmuştur. $\mathrm{Bu}$ jurnallerin imhasına dair ayrıntılı raporların şimdiye kadar bulunmamış olması, hatta imha emrinin kim tarafından verildiğinin belirsizliği de, dönemin aktörlerinin ne denli bir endişe içinde olduklarını ve jurnalleri -Osmanlı tarihine ışı tutacak niteliğe sahip olduğunun bilinmesine rağmen- sırf yok etmek amacıyla imha ettiklerini anlatmak için yeterlidir.

2. Daha sonra kullanma kaygısına sahip imha uygulamaları: Osmanlı döneminde evrak imha uygulamalarının daha ziyade belli bir kaygı taşıdığı söylenebilir. Yeniçeri ocağına ait evrak ve defterlerin imhası kararının verilmesi, 1848-1850 yıllarına ait bazı evrakın imhası ve 1903 yılına ait imha kararları bu türden kaygıların başat rol oynadığı uygulamalardır. 1914 yılında hazırlanan imha nuzamnâmesi de bu uygulamaların belli kaygıları temel alan uygulamalar olduklarını açık bir şekilde ortaya koymaktadır. İdarî, malî ve hukukî içerikli nedenler taşıyan bu kaygılar, evrakın genellikle sonraki vatandaş, kurum ve kamu işlemlerinde kullanılması ihtimaline karşılık gelmektedir.

Bu nizamnâmede evrakın korunmasında belli kriterler belirlenmiştir. Bu kriterler; kurumlarca üretilen evrakın neden korunduğuna işaret eden ve günümüzde de geçerli olan iki nokta üzerinde durmaktadır: 
1. Belgenin işlemlere dayanak olarak kullanıldığını ortaya koyan idarî değeri.

2. Belgenin şahısların ve kurumların haklarının muhafazasında kullanıldığını ifade eden hukuî değeri.

Burada ifade edilmeyen malî denetim gibi işlemlere dayanak teşkil ettiğini düşünebileceğimiz malî içeriğe sahip evrakın da malî değerinin olduğudur. Ancak -zamanın idarî terminolojisinin muhtemelen günümüzdeki kadar ayrıntılanmadığg dikkate alınacak olursa- bu değerin idarî değer içinde değerlendirilmiş olabileceği yorumunun yapılması mümkündür. Bu her iki değere sahip olmadığına kanaat getirilen evrakın lüzumsuz olduğu kararlaştırılmış ve korunmasına devam edilmesinin gereksiz masrafa ve depodaki belgelerin araştırılmasının/erişiminin -muhtemelen belgelerin oluşturduğu hacimli yığınlar nedeniyle- büyük güçlüklere yol açacağı üzerinde durulmuştur. Ancak burada eksik olan bir husus bulunmaktadır; o da, korunması öngörülen evrakın gelecekte bilimsel araştırmalara kaynaklık etmesi bakımından korunması arzusudur.

Evrakın imhası yönünde gerçekleştirilen bu iki yöntemden her birinin arşivcilikteki imha teorisi bakımından değerlendirilmesi, bizi, birbirinden tamamen farklı sonuçlara ulaştırmaktadır. Bunlardan birincisinin, yani sadece imha düşüncesinin hâkim olduğu eğilimin imha teorisi bakımından bir önemi haiz değildir. Zira burada evrakı sadece imha etmek temel kaygıdır ve bunun dışında herhangi bir kaygının hesaba katılmadığı da açıktır. Bu bakımdan, bu uygulamanın imha teorisine verdiği bir katkıdan da söz edilemez. Yani bu uygulamaların Osmanlı imha teorisi bağlamında bir anlam ifade ettiğinin düşünülmesi ve bunun Osmanlı imha uygulamasına bir karakter kazandırması mümkün değildir.

İkinci uygulamanın ise arşivcilik teorisi yönünden önemli olduğu söylenebilir. Burada günümüz arşivcilik anlayışına uygun bir değerlendirme mantığının bulunduğu da açıktır. Zira değerlendirme işlemi ile evrakın, kurumların mevcut ihtiyaçları sırasında araştırmaları güçleştirdiği, gelecekteki faaliyetleri ve gerek kurumların gerekse şahısların haklarının muhafazasında bir aktör olarak işlev görebileceği üzerinde durulmuş; böylelikle de, söz konusu evrakın sonraki dönemde kullanılıp kullanılmayacağı sorgulanmıştır. Bu kaygının günümüz evrakının korunmasında ve imha uygulaması sırasında muhafaza edilmek üzere ayrılan evrakın belirlenmesinde de etkili olduğu bilinmektedir. Ancak bu uygulamaların hiç birinde, -bugün olduğu gibi- evrakın araştırma değeri nedeniyle sürekli saklanması gereği üzerinde açık bir şekilde durulmamıştır. Yani belgelerin kanıtsal değeri üzerinde durulmuş ancak bilgisel değeri üzerinde durulmamıştır.

Osmanlı idare geleneğinde tarihi evrakın araştırma değerinin dikkate alındığını gösterme ihtimali olan bir istisna uygulama vardır. Harbiye Nezareti'nde kurulması düşünülen Savaş Arşivi (Harb Hazîne-i Evrâkı) adında bir birimin kurulması çalışması sırasında yapılan yazışmada kullanılan ifade belli belirsiz bir araştırma değeri meselesinden söz etmektedir. Bu bakımdan Osmanlı dönemi imha uygulamalarında evrakın “araştırma değeri”nin -belki- üstü kapalı bir 
şekilde hesaba katıldığı söylenebilir. Örneğin; söz konusu uygulamada tarihe 1şık tutabilecek evrakın korunması arzusu yani Harbiye Nezareti'ne bağlı Târîh-i Harb Şu'besi'ne bağlı Harb Hazîne-i Evrâkı için tarihi önemi haiz evrakın buraya nakledilmesi, bu yönde bir algının mevcudiyeti konusunda ipuçları sunmaktadır. 1917'de Harbiye Nezâreti bünyesinde kurulan Târîh-i Harb Şu'besi'ne bağlı Harb Hazîne-i Evrâkı için harp tarihiyle alakalı vesikaların bir araya toplanmasının istenmesi, bu duruma üstü kapalı bir cevap olabilir niteliktedir. Belgede zikredilen "[...] esfâr-1 sâlifeye ve sefer-i lâhikaya müte'allik vesâ'ik iktitâf ve tasnîf edilmek üzere bir de Harb Hazîne-i Evrâkı te'sîs kılındığı [...]" (BOA. MV., 209/2; Belgelerle arşivcilik tarihimiz, 2000, ss. 447-448) şeklindeki ifade bunu doğrulamaktadır. Ancak burada sadece önceki dönemlere ait savaş taktiklerinin uzman personel yetiştirme ile kurumsal hatta millî askerî ihtiyaçlar bakımlarından bilinmesi arzu edilmiş de olabilir.

İlgili yazışmada açık bir şekilde araştırma ihtiyacı ve araştırmacılardan söz edilmemiş olsa da, Harbiye Nezâreti'nin eski dönemlerde gerçekleşmiş savaş taktiklerini araştırmak üzere bir arşiv teşekkül ettirdiği açıktır. Bunun dönemin Avrupa ülkelerinde gelişmiş bir eğilim olduğu dikkate alınacak olursa, yani o dönemin Batılı ülkelerinin "savaş arşivi”" tarzında kurumlar teşekkül ettirdikleri konusu dikkate alınacak olursa, Osmanlı askeri yetkililerinin de benzer bir ihtiyacın farkında olduklarını ve bu ihtiyacı karşılamak üzere kurumsal bir bakış açısı geliştirdikleri iddia edilebilir. Ama yine de, o günün Osmanlı bilim anlayışında bir süredir dikkate alınan arşiv belgelerinin bilimsel araştırmalarda kullanılabileceği yönündeki bakış açısının çok yaygın olmayan bir durum olduğu; bu yüzden bunun açıkça ifade edilmediği de bir gerçektir. Nitekim gerek Tarih-i Osmani Encümeni'nin faaliyetleri ve yayın organı olarak hayata geçirilen Tarih-i Osmani Encümeni Mecmuası'nda arşiv belgelerinden yararlanılarak kimi makalelerin kaleme alınmış olmasından (örneğin ilgili dergide yayınlanan 152 makaleden 70'inde arşiv belgeleri yayımlanmıştır -Kurt, 2020, s. 61-) ve Macar tarihçi İmre Karaçon (18631911, Imre -Emeric- Karácson) gibi bazı bilim insanlarının zamanın Osmanlı arşivlerinden yararlanmaları (Çetin, 1983, ss. 169-172; Çetin, 2012, ss. 379-380) gerekse Hayreddin Nedim (Göçen) gibi bürokrat, yazar ve arşivci kimliğine sahip bazı şahısların arşivlerin bilimsel çalışmalarda kullanılabileceği yönündeki bakış açılarının varlığı (Hayreddin, 2008, ss. 3-4; Keskin, 2008, ss. 260-266; Keskin ve Günalan, 2011, ss. 343, 348-349), Osmanlı bürokratlarının imha kararı verirken bu belgelerin tarihî araştırmalarda kullanılabilirlik değerlerinin olduğunu göz önünde bulundurdukları, ancak bürokratik ihtiyaçlar göz önüne alınarak hayata geçirilen imha uygulamalarının gerekçelendirilmesi sırasında bundan açık bir şekilde söz edilmediği üzerinde durulabilir. Kesin şekilde dikkate alınan ise idarî, malî ve hukukî süreçlerde kullanılma ihtimali olan kayıtların kesin şekilde korunması eğilimidir.

\section{SONUÇ}

Osmanlı kurumlarının ürettiği belgelerin tamamı günümüze ulaşmamıştır. İlgisizlik, dikkatsizlik, ihmal, depo şartlarında yetersizlik, bilinçsizlik, nakil (taşınma), su baskınları, 
kasıt, yangın, savaş ve iç asayiş sorunları bunun önemli nedenleri arasındadır. Bu sebeplerin dışında, yasal izinler alınmak suretiyle evrakın imha edildiği örnekler de vardır. Ancak bu örneklerin tamamı günümüz evrak imha uygulamaları bakımından kabul edilebilir gerekçelere sahip değildir. Aksine bir kısım imha uygulamaları kabul edilebilir gerekçelere sahip iken, diğer bir kısım uygulamaların kabul edilebilir bir gerekçesi bulunmamaktadır. Hatta herhangi bir gerekçe sunulmadan gerçekleştirilen imha uygulaması bile mevcuttur.

Osmanlı Devleti'nin son zamanlarına doğru bazı evrak imha uygulamaları hayata geçirilmiştir. Bunların bir kısmı sadece evrakı imha etme kaygısına sahiptir. Örneğin; II. Abdülhamid dönemini (sal. 1876-1909) sonlandıran ihtilal idaresi tarafından imha edilen istihbarat jurnalleri meselesi, imha uygulamasının sadece evrakı yok etmek kaygısıyla gerçekleştirildiğini göstermektedir. Diğer yandan evrakın sonraki süreçlerde kullanılma ihtimalinin sorgulandığı imha uygulamaları da mevcuttur. II. Mahmud döneminde (sal. 1808-1839) Yeniçeri ocağına ait bazı defterlerin imhas1, 1848-1850 yıllarına ait bazı evrakın ve defterlerin imhası, 1903 yılına ait imha kararı ve 1914 yılına ait benzeri bir karar ile 1917 yılına ait evrak imhasıyla ilgili nizamnâme layihası çalışması bu türden kaygıların başat rol oynadığı uygulamalardır. Bu uygulamaların önemli bir kısmının kabul edilebilir idarî, hukukî ve malî -hatta kısmen bilimsel- nedenlere dayandırılmış olması dikkat çekicidir. II. Abdülhamid dönemi istihbarat jurnallerinin imha edilmesi ise tamamen sübjektif bir davranışın ürünüdür ve modern arşiv teorisi bakımından bir anlam taşımamaktadır.

Uygulamalardan ve yapılan çalışmalardan hareketle Osmanlı imha uygulamasının belli bir altyapısının olduğu anlaşılmaktadır. Bu altyapı genellikle günümüz arşivciliğinin bilimsel bakış açısı ile örtüşmektedir. Osmanlı dönemi imha uygulamalarının iki temel karakteri vardır:

1. Kasıtlı imha: Bu uygulamada evrakın kasten yok edilmesi ve onların sonraki dönemlerde kullanılma ihtimalinin göz ardı edilmesi söz konusudur.

2. Kullanma kaygısına sahip imha: Osmanlı döneminde gerçekleştirilen evrak imha uyulamalarının ortaya koyduğu önemli ayrıntı idarî, malî, hukukî bir nedene bağlı olarak gelecekte kullanılmayacak evrakın imha edilmesidir. Bu, üzerinde görüş birliği oluşmuş bir bakış açısını yansıtmaktadır. Ancak idarî, malî ve hukukî bir öneme sahip olmayacak evrakın ise imha edilebileceği kabul görmüştür.

Evrakın imhası yönünde hayata geçirilmiş olan bu iki yöntemden her birinin arşiv imha teorisi bakımından değerlendirilmesi, bizi, birbirine zıt iki sonuca ulaştırır:

1. Evrakın sadece yok edilmesi düşüncesinin hâkim olduğu eğilim: Sadece imha düşüncesinin hâkim olduğu eğilimin imha teorisi bakımından bir önemi yoktur. Evrakı bir daha kullanılmayacak şekilde imha etmek temel kaygıdır. 
2. Amaç ve kaygıları bakımından devlet, kurum ve şahıs ihtiyaçlarını dikkate alan eğilim: $\mathrm{Bu}$ eğilimde günümüz arşivcilik anlayışına uygun bir değerlendirme mantığı vardır. Evrak imhasına yönelik bu grup altında yapılan değerlendirmeler, depolarda bulunan evrak yığınlarının idarî amaçlı arşiv araştırmalarını güçleştirdiği, kurumsal faaliyetlerin planlanmasında zorluk yarattığı ve kurumlar ile şahısların haklarının korunmasında bir faktör olarak işlev görebileceği şeklindedir.

Osmanlı dönemi imha uygulamaları arasından sadece biri evrakın “araştırma değeri”nin hesaba katılmış olabileceğini göstermektedir. Çünkü bu uygulama tarihe ışık tutabilecek evrakın korunmasına yönünde bir bakış açısını içinde barındırmaktadır. Ancak bu bakış açısının bilimsel çalışmalara kaynak sağlama amacı güdüp-gütmediği belirsizdir. İmha uygulamalarında genel olarak araştırma ve araştırmacılardan söz edilmemiş olsa da, hayata geçirilen iki örnek bu konuda farklı bakış açısı geliştirmeye imkân tanır. Harbiye Nezâreti'nin eski dönemlerde gerçekleşmiş savaş taktiklerini araştırmak üzere bir "Savaş Arşivi” teşekkül ettirilmesi sırasında yapılan yazışma bu konuda bir fikir verebilir niteliktedir. Söz konusu Savaş Arşivi için savaş tarihiyle alakalı vesikaların bir araya toplanmasının istenmesi, bir anlamda evrakın bilimsel araştırma değerinin bilindiğine yönelik üstü kapalı bir cevap gibidir. Ancak yine de konunun askerî ihtiyaçlar bağlamında değerlendirilip önceki dönemlere ait savaş taktiklerinin personel eğitimi ve askerî ihtiyaçlar bakımlarından bilinmesinin arzu edilmiş olması da mümkündür. O dönemin Batılı ülkelerinin "savaş arşivi” tarzında kurumlar teşekkül ettirdikleri konusu dikkate alınacak olursa, Osmanlı askeri yetkililerinin de benzer bir ihtiyacı gidermeyi düşündükleri ve bu yönde bir bakış açısı geliştirdikleri söylenebilir. Ancak yine de, o günün Osmanlı bilim anlayışında bir süredir dikkate alınan arşiv belgelerinin bilimsel araştırmalarda kullanılabileceği yönündeki bakış açısının çok yaygın olmayan bir durum olduğu; bu yüzden de bunun açıkça ifade edilmediği de bir gerçektir.

Hakem Değerlendirmesi: Dış bağımsız.

Çıkar Çatışması: Yazar çıkar çatışması bildirmemişstir.

Finansal Destek: Yazar bu çalışma için finansal destek almadığını beyan etmiştir.

Peer-review: Externally peer-reviewed.

Conflict of Interest: The author has no conflict of interest to declare.

Grant Support: The author declared that this study has received no financial support.

\section{Kaynakça/References}

\section{Arşiv Belgeleri}

Bâb-ı Âlî Evrak Odası (BEO, 335986). Başkanlık Osmanlı Arşivi, İstanbul. Bâb-1 Âlî Evrak Odası (BEO, 769/51). Başkanlık Osmanlı Arşivi, İstanbul. 
Bâb-1 Âlî Evrak Odası (BEO, 770/29). Başkanlık Osmanlı Arşivi, İstanbul.

Dahiliye Nezareti Emniyet-i Umumiye Müdüriyeti Muhasebe Kalemi (DH. EUM. MH., 123-17). Başkanlık Osmanlı Arşivi, İstanbul.

Dahiliye Nezareti Mebânî-i Emîriye ve Hapishaneler (DH. MB. HPS., 46/42). Başkanlık Osmanlı Arşivi, İstanbul.

Dahiliye Nezareti Muhaberat-1 Umumiye İdaresi Evrakı (DH.MUI., 55-1/7, 1328.M.14). Başkanlık Osmanlı Arşivi, İstanbul.

Dahiliye Nezareti Mütenevvia Evrakı (DH. MTV., 47/4). Başkanlık Osmanlı Arşivi, İstanbul.

Dahiliye Nezâreti Sicill-i Nüfus İdare-i Umumiyesi Tahrirat Kalemi (DH. SN. THR., 8/62). Başkanlık Osmanlı Arşivi, İstanbul.

Dahiliye Nezâreti Sicill-i Nüfus İdare-i Umumiyesi Tahrirat Kalemi (DH. SN. THR., 68/83). Başkanlık Osmanlı Arşivi, İstanbul.

Dahiliye Nezâreti Sicill-i Nüfus İdare-i Umumiyesi Tahrirat Kalemi (DH. SN. THR., 71/11). Başkanlık Osmanlı Arşivi, İstanbul.

Dahiliye Nezâreti Sicill-i Nüfus İdare-i Umumiyesi Tahrirat Kalemi (DH. SN. THR.. 81/70). Başkanlık Osmanlı Arşivi, İstanbul.

İrade Dahiliye (İ. DH., 1316 R./17). Başkanlık Osmanlı Arşivi, İstanbul.

İrade Dahiliye (İ. DH., 5152). Başkanlık Osmanlı Arşivi, İstanbul.

İrade Dosya Usulü (İ.DUIT., 37-2/11-6). Başkanlık Osmanlı Arşivi, İstanbul.

İrade Meclis-i Vala (İ. MVİ., 6536). Başkanlık Osmanlı Arşivi, İstanbul.

İrade Mesail-i Mühimme (İ. MSM., 25/658). Başkanlık Osmanlı Arşivi, İstanbul.

İrade Sıhhiye (İ. SH., 1317 R./1). Başkanlık Osmanlı Arşivi, İstanbul.

İrade Şura-yı Devlet (İ. ŞD., 2450). Başkanlık Osmanlı Arşivi, İstanbul.

İrade Şura-yı Devlet (İ. ŞD., 3560). Başkanlık Osmanlı Arşivi, İstanbul.

İrade Şura-yı Devlet (İ. ŞD., 4436). Başkanlık Osmanlı Arşivi, İstanbul.

Meclis-i Vükelâ Mazbataları (MV., 209/2). Başkanlık Osmanlı Arşivi, İstanbul.

Mütenevvî Maruzat Evrakı (Y.MTV., 252/64). Başkanlık Osmanlı Arşivi, İstanbul.

Sadâret Resmî Maruzât Evrakı (Y. A. RES., 108/82). Başkanlık Osmanlı Arşivi, İstanbul.

Yıldız Esas Evrakı (Y. EE., 30/124/51/78). Başkanlık Osmanlı Arşivi, İstanbul.

\section{Kaynak ve Araştırma Eserleri}

Abdurrahman Şeref Bey. (1326). Evrak-1 atîkamız ve vesâik-i târihiyyemiz. Tarih-i Osmanî Encümeni Mecmuası, I, 9-19.

Ahmed Lûtfî Efendi. (1999). Vak'anüvîs Ahmed Lûtfí Efendi tarihi (Ciltler 6-7-8) (Y. Demirel, Yay. Haz.). İstanbul: Yapı Kredi Yayınları. (Orijinal'i 1328'de yayımlanmıştır).

Ahmed Lütfi Efendi. (1328). Tarih-i Lütfi (Cilt VIII). İstanbul: Sabah Matbaas1.

Aktaş, N. (1985). Osmanlı dönemi arşivciliğimiz ve tasnif çalışmaları. Belgelerle Türk Dünyası Tarih Dergisi, $1,67-72$.

Aktaş, N. (2000). Osmanlı dönemi arşivciliğimiz ve tasnif çalışmaları. Uluslararası kuruluşunun 700. Yıldönümü’nde Bütün Yönleriyle Osmanlı Devleti Kongresi -07-09 Nisan 1999- Konya-içinde (ss. 379387). Konya: Selçuk Üniversitesi Yayınları. 
Akyıldız, A. (1993). Tanzimat dönemi Osmanlı merkez teşkilatında reform (1836-1856). İstanbul: Eren Yayınc1lık. Akyıldız, A. (1995). Hazîne-i Evrak'ın kurulması ve ilk tasnif usulleri (1846-1856). Hakkı Dursun Yıldız Armağanı içinde (ss. 69-84). İstanbul: Marmara Üniversitesi Edebiyat Fakültesi Yayınları.

Akyıldız, A. (2004). Osmanlı bürokrasisi ve modernleşme. İstanbul: İletişim Yayınları.

Aydın, B. (1999). Osmanlı Devleti'nde evrak imha ve muhafazasına dair neşredilen ilk nizamname layihası. Arşiv Araştırmaları Dergisi, 1, 47-54.

Başar, F. (1995). Fetret devri. Türkiye Diyanet Vakfi İslam ansiklopedisi. https://islamansiklopedisi.org.tr/ fetret-devri adresinden erişildi.

Beyhan, M. A. (2002). II. Abdülhamid döneminde Hafiye Teşkilatı ve jurnaller. H. C. Güzel, K. Çiçek ve S. Koca (Ed.), Türkler cilt 12 içinde (ss. 252-272). Ankara: Yeni Türkiye Yayınları.

Binark, İ. (1980/a). Arşivlerimizin değeri ve son vakanüvis Abdurrahman Şeref Bey’in ‘evrak-1 atika ve vesaik-i tarihiyyemiz’ adlı yazısı. Türk Kütüphaneciler Derneği Bülteni, 29(1), 23-38. http://www.tk.org.tr/index. $\mathrm{php} / \mathrm{TK} /$ article/view/1525/1516 adresinden erişildi.

Binark, İ. (1980/b). Arşiv ve arşivcilik bilgileri. Ankara: Devlet Arşivleri Genel Müdürlüğü.

Candemir, M. (2011). Son yıldız düşerken. İstanbul: Çamlıca.

Çetin, A. (1983). Arşivlerimiz hakkında ‘İkdam' Gazetesi’nin bir yazısı ve düşündürdükleri. Türk Kütüphaneciler Derneği Bülteni, 32(4), 168-176. http://www.tk.org.tr/index.php/TK/article/view/2861/2786 adresinden erişildi.

Çetin, A. (1984). Osmanlı arşivciliğine toplu bir bakış. Türk Kütüphaneciler Derneği Bülteni, 33(2), 53-65. http://www.tk.org.tr/index.php/TK/article/view/1449/1441 adresinden erişildi.

Çetin, A. (1987). İstila-yı keferede kalan Osmanl defterleri. Türk Dünyası Tarih Dergisi, 3, 6-8.

Çetin, A. (2012). Karácson, Imre (Emeric). Türkiye Diyanet Vakfi İslam ansiklopedisi. https://islamansiklopedisi. org.tr/karacson-imre-emeric adresinden erişildi.

Çınar, A. O. (1999). Mehmed Emin Edîb Efendi'nin hayatı ve Tarih'i (Doktora tezi). Marmara Üniversitesi Açık Erişim Sistemi. (Kayıt No. T0045757).

Dearstyne, B. (2001). Arşivsel girişim. Modern arşivcilik ilkeleri, uygulamaları ve yönetim teknikleri (M. Akbulut ve A. O. İcimsoy, Çev.), İstanbul. (Orijinali 1992'de yayımlanmıştır).

Demiroğlu, F. (1955). Abdülhamid'e verilen jurnaller. İstanbul: Tarih Kütüphanesi Yayınları.

Devlet Arşivleri Başkanlığı Hakkında Cumhurbaşkanlığı Kararnamesi. (2018, 16 Temmuz). Resmî Gazete (Kararname Numaras1: 11, Say1: 30480). https://www.resmigazete.gov.tr/eskiler/2018/07/20180716-1. pdf adresinden erişildi.

Devlet Arşivleri Genel Müdürlüğü. (2000). Başbakanlık Osmanlı Arşivi rehberi (2. bas.). Ankara: DAGM

Devlet Arşivleri Genel Müdürlüğü. (2000). Belgelerle arşivcilik tarihimiz I (Osmanlı Dönemi). Ankara: DAGM

Duchein, M. (2008). Provenans prensibi ve çağdaş arşivcilikte tanımlama, düzenleme ve ayıklama uygulaması (T. Aren, Çev.). İ. Keskin (Haz.), Arşivcilik metinleri içinde (ss. 31-53), İstanbul: Yeditepe. (Orijinali 1998'de yayımlanmıştır).

Emecen, F. M. (1991). Sefere götürülen defterlerin defteri. Prof.Dr. Bekir Kütükoğlu'na armağan içinde (ss. 241-268). İstanbul: İ.Ü. Edebiyat Fakültesi.

Findley, C.V. (1994). Osmanlı devletinde bürokratik reform. Bâbıâli (1789-1922) (L. Boyacı ve İ. Akyol, Çev.). İstanbul: İz yayıncılık. 
Resmi Evrak Neden Saklanır/İmha Edilir? Osmanlı İmparatorluğu’nda Evrak İmha Uygulamalarına Yönelik...

Findley, C.V. (1996). Kalemiyeden mülkiyeye. Osmanlı memurlarının toplumsal tarihi (G. Çağalı Güven, Çev.). İstanbul: Tarih Vakfı Yurt Yayınları.

Hayreddin [Nedim Göçen]. (2008). Belgelerin dilinden Osmanlı ve Avrupa (vesâik-i târihiyye ve siyâsiyye tetebbuâtı). İ. Keskin ve A. Ahmetbeyoğlu (Yay. Haz.), İstanbul: Selis Kitaplar.

İnal, İ. M. K. (1964). Osmanlı devrinde son sadrazamlar. İstanbul: Milli Eğitim Bakanlığı Basımevi.

İnalcık, H. (1988). Türk -Osmanlılar kısmı-. Diyanet İslam Ansiklopedisi (Cilt. XII/2). İstanbul: Milli Eğitim Bakanlı̆̆1.

Jenkinson, H. (1922). A manual of archive administration. Including the problems of war archives and archive making. Oxford: Clarendon Press.

Kandur, H. (1998). Belediyelerde arşiv yönetimi. İstanbul: Remak.

Keskin, İ. (2008). Günümüz arşivcilik anlayışıyla bir Osmanlı aydını olarak Hayreddin Bey [Nedim Göçen]'in (1867-1942) arşivcilik anlayışının karşılaştırılması. Journal of Turkish Studies -In Memoriam Şinasi Tekin III-, 32(1), 289-306.

Keskin, İ. ve Günalan, R. (2011). Hayreddin Nedim Bey’in [Göçen] kaleminden arşivcilik. E. Balta, Y. Dedes, E. N. İşli, M. S. Koz (Yay. Haz.), Yücel Dağlı Anısına (ss. 332-353) içinde. İstanbul: Turkuaz.

Kurt, S. (2020). Tarih-i Osmani Encümeni/Türk Tarih Encümeni Mecmuasında vesika aktarımı. Arşiv Dünyası, 7(1), 59-76. https://dergipark.org.tr/tr/download/article-file/1170447 adresinden erişildi.

Lamb, W. K. (1985). The fine art of destruction. In Peter Walne (Ed.), Modern archives administration and records management: A RAMP reader (pp. 251-257). Paris: UNESCO.

Osman Nuri ve Mehmed Hayati. (1332). Evrâk-ı atîkanın sûret-i tasfiyesine dâir rapor. İstanbul.

Osmanlı Arşivi Tarihçesi. (1990). Osmanlı Arşiv Bülteni, 1, 9-20.

Rukanc1, F. ve Anameriç, H. (2006). Evrak-1 atikanın suret-i tasfiyesine dair rapor. Belgeler, 27/31, 91-134.

Schellenberg, T. R. (1956). Modern archives: principles and techniques. Chicago: University of Chicago Press.

Schellenberg, T. R. (1965). The Management of archives. New York: Columbia University Press.

Schellenberg, T. R. (1975). Modern archives: principles and techniques. Chicago: University of Chicago Press.

Schellenberg, T. R. (1998). Modern archives: principles and techniques. Chicago: University of Chicago Press.

Schellenberg, T.R. (1985). Principles of archival appraisal. In Peter Walne (Ed.), Modern archives administration and records management: A RAMP reader (pp. 269-279). Paris: UNESCO.

Schellenberg, T.R. (1993). Arşiv idaresi. N. İlemin (Çev.). Ankara: Devlet Arşivleri Genel Müdürlüğü. (Orijinal basim tarihi 1965).

Schellenberg, T.R. (2008). Arşivsel değerlendirme ilkeleri (İ. Bozan, Çev.). İshak Keskin (Haz.), Arşivcilik metinleri içinde (ss. 55-70). İstanbul: Yeditepe. (Orijinali 1985'te yayımlanmıştır).

Tugay, A. (1935). İbret - Abdülhamid'e verilen jurnaller ve jurnalciler. İstanbul: Okat Yayınevi.

Uşaklıgil, H. Z. (1942). Saray ve Ötesi (Cilt III). İstanbul: İnkılap ve Aka Yayınları.

Uzunçarş11, İ. H. (1988). Osmanlı Devleti'nin merkez ve bahriye teşkilatı (3. bs.). Ankara: Türk Tarih Kurumu.

Walne, P., Evans, F. B. ve Himly, F. J. (Ed.). (1995). Arşivcilik terimleri sözlüğü (B. K. Ataman, Çev. ve Gnş.). İstanbul: Librairie de Péra. (Orijinali 1984’te yayımlanmıştır).

Yalçın, H. C. (2000). Siyasal anılar. İstanbul: Türkiye İş Bankası Yayınları. 